\title{
SARS-COV-2 Variants: Differences and Potential of Immune Evasion
}

\begin{abstract}
Sandro M. Hirabara ${ }^{1 *}$, Tamires D. A. Serdan ${ }^{2 \dagger}$, Renata Gorjao ${ }^{1}$, Laureane N. Masi ${ }^{1}$, Tania C. Pithon-Curi ${ }^{1}$, Dimas T. Covas ${ }^{3,4}$, Rui Curi ${ }^{1,5}$ and Edison L. Durigon ${ }^{6,7}$

1 Interdisciplinary Program of Health Sciences, Cruzeiro do Sul University, São Paulo, Brazil, ${ }^{2}$ Department of Molecular Pathobiology, New York University, New York, NY, United States, ${ }^{3}$ Butantan Institute, São Paulo, Brazil, ${ }^{4}$ Ribeirão Preto Medical School, University of São Paulo, Ribeirão Preto, Brazil, ${ }^{5}$ Immunobiological Production Section, Bioindustrial Center, Butantan Institute, São Paulo, Brazil, 6 Laboratory of Clinical and Molecular Virology, Department of Microbiology, Institute of Biomedical Sciences, University of São Paulo, São Paulo, Brazil, ${ }^{7}$ Scientific Platform Pasteur University of São Paulo, São Paulo, Brazil
\end{abstract}

The structural spike (S) glycoprotein of severe acute respiratory syndrome coronavirus-2 (SARS-CoV-2) plays an essential role in infection and is an important target for neutralizing antibody recognition. Mutations in the $S$ gene can generate variants of concern (VOCs), which improve "viral fitness" through selective or survival advantages, such as increased ACE-2 receptor affinity, infectivity, viral replication, higher transmissibility, resistance to neutralizing antibodies and immune escape, increasing disease severity and reinfection risk. Five VOCs have been recognized and include B.1.1.7 (U.K.), B.1.351 (South Africa), P.1 (Brazil), B.1.617.2 (India), and B.1.1.529 (multiple countries). In this review, we addressed the following critical points concerning VOCs: a) characteristics of the SARS-CoV-2 VOCs with mutations in the $S$ gene; b) possible evasion of variants from neutralizing antibodies generated through vaccination, previous infection, or immune therapies; c) potential risk of new pandemic waves induced by the variants worldwide; and d) perspectives for further studies and actions aimed at preventing or reducing the impact of new variants during the current COVID-19 pandemic.

Keywords: COVID-19, variant of concern, neutralizing antibody, vaccines, immune escape, delta variant, omicron variant

\section{INTRODUCTION}

Severe acute respiratory syndrome coronavirus-2 (SARS-CoV-2) is a single-stranded positive-sense RNA virus containing a genome with 29,903 nucleotides and 29 proteins (Focosi and Maggi, 2021). The virus has six major open-reading frames (ORFs): ORF1a, ORF1b, S (spike), E (envelope), $\mathrm{M}$ (membrane), and $\mathrm{N}$ (nucleocapsid), and several accessory ORFs: ORF3a/b, ORF6, ORF7a, ORF7b, ORF8, ORF9b/c, and ORF10 (Kim et al., 2020; Zhu et al., 2020; Finkel et al., 2021).

ORF1a and ORF1b account for two-thirds of the SARS-CoV-2 genome. ORF1a encodes the polyprotein PP1a and the polyprotein PP1ab is a result of the overlapping translation of ORF1a and ORF1b. Both polyproteins (PP1a and PP1ab) are cleaved into 16 nonstructural proteins (NSPs 1 to 16): NSP1 (leader protein), NSP2 (unknown function), NSP3 (papain-like proteinase), NSP4 (transmembrane nsp containing four transmembrane domains and one luminal domain), NSP5 (3C-like proteinase), NSP6 (putative transmembrane nsp containing six transmembrane domains and two small luminal domains), NSP7 and NSP8 (the NSP7-NSP8 heterodimer interacts with the NSP12 
forming the RNA polymerase complex), NSP9 (RNA-binding protein), NSP10 (cofactor for nsp14 and nsp16), NSP11 (unknown function), NSP12 (RNA-dependent RNA polymerase, RdRp), NSP13 (helicase), NSP14 ( $3^{\prime}$ to $5^{\prime}$ Endonuclease, N7Methyltransferase), NSP15 (endoribonuclease, NendoU), and NSP16 (2'-O-Ribose-Methyltransferase) (Snijder et al., 2016; Finkel et al., 2021). ORFs S, E, M, and N encode four structural proteins, whereas accessory ORFs lead to the formation of several accessory proteins (Kim et al., 2020) (Figure 1).

The $\mathrm{M}$ protein is the most abundant transmembrane protein and is associated with virus assembly and morphology. The E protein also participates in virus assembly, release, and ion channel activity processing. In coronaviruses, ion channel activity has been implicated in viral infectivity. The $\mathrm{N}$ protein encapsulates the viral RNA and, along with NSPs, plays a crucial role in virus replication, transcriptional processes, and genome assembly (Nieto-Torres et al., 2014; Abdel-Moneim et al., 2021).

The $\mathrm{S}$ glycoprotein is a homotrimer, and each monomer contains two subunits, S1 and S2. S1 contains the N-terminal domain (NTD) and the receptor-binding domain (RBD), which recognize and bind to the angiotensin-converting enzyme-2 (ACE-2) receptor required for virus attachment and entry into host cells (Ou et al., 2020; Abdel-Moneim et al., 2021). The RBD, precisely the receptor-binding motif (RBM) region, also contains the main antigenic epitopes recognized by neutralizing antibodies (nAbs) (Abdel-Moneim et al., 2021). S2 has several domains and mediates membrane fusion between the viral envelope and the host cell (Abdel-Moneim et al., 2021). The S protein is highly

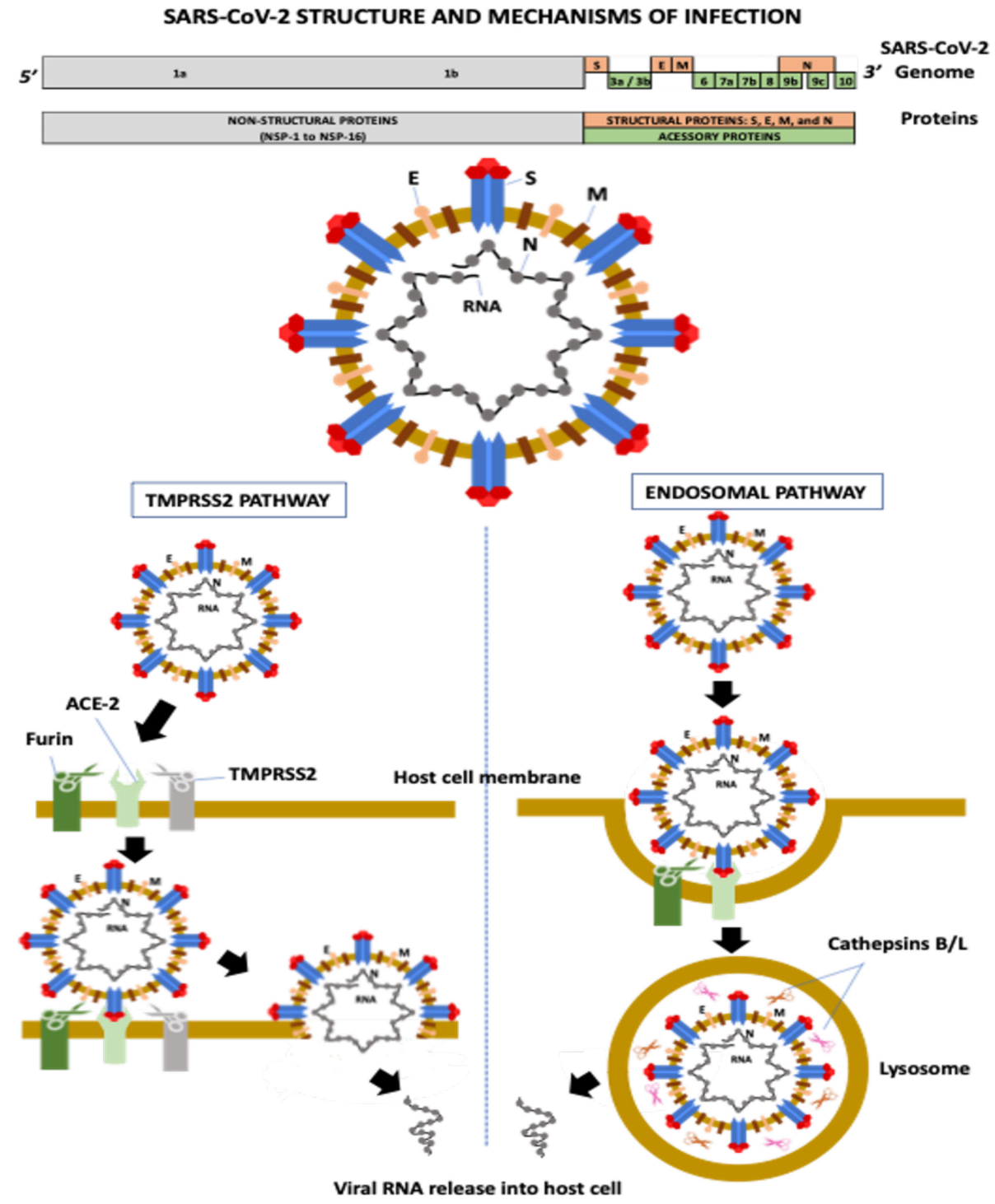

FIGURE 1 | SARS-CoV-2 structure and mechanisms of infection. ACE-2, angiotensin-converting enzyme-2; E, envelope; M, membrane; N, nucleocapsid; NSP, non-structural protein; S, spike; TMPRSS-2, transmembrane serine protease-2. 
$\mathrm{N}$-glycosylated at at least 22 sites: 13 in S1 and nine in S2 (Yao et al., 2020). Two main RBD conformations have been described, standing-up and lying-down states, with high and low affinity to ACE2, respectively (Yao et al., 2020). Although RBD of SARSCoV-2 presents a higher affinity to ACE2 than the RBD of SARS$\mathrm{CoV}$, most RBD in the entire SARS-CoV-2 is in the lying-down state, resulting in a similar or even lower affinity to the receptor than SARS-CoV (Yao et al., 2020). The exposure of N-linked glycans is modified according to the RBD conformation (10 in the RBD-down and 7 in the RBD-up states), suggesting that these molecules can participate in the interaction between SARS-CoV-2 and the host cell (Yao et al., 2020).

The first step of viral infection is RBD binding to ACE2 on the host cell. Several proteases then help S glycoprotein cleavage, including transmembrane serine protease- 2 and -4 (TMPRSS- 2 and -4), furin-like enzymes, and endosomal cathepsins B/L (Shang et al., 2020) (Figure 1). Cleavage is required for $S$ protein priming and activation, allowing the membrane fusion process and viral RNA entry into a host cell (Hoffmann et al., 2020; Zang et al., 2020). The activity of these proteases is associated with increased transmissibility, virulence, and cell and tissue tropism (Abdel-Moneim et al., 2021).

Furin is a serine protease involved in the preactivation of the $S$ protein, which enhances virus entry mainly in host cells with low expression of other proteases, including TMPRSS2 and cathepsins (Shang et al., 2020). The protease recognizes the furin-like cleavage site, a multibasic site composed of three arginine molecules and one alanine (RRAR) located at the S1$\mathrm{S} 2$ junction. After this cleavage preactivation of the S protein ( $\mathrm{S} 1-$ S2 junction), a second cleavage site located in the S2 subunit (S2' site) is critical for membrane fusion during virus entry (Takeda, 2022). The cleavage of the S2' site occurs by two pathways: a) the TMPRSS2 pathway and b) the endosomal pathway (Hoffmann et al., 2020) (Figure 1). TMPRSS2 is a serine protease with trypsin-like endopeptidase activity located at the cell surface that promotes priming and activation of the $S$ protein, allowing the interaction of the S2 fusion peptide (FP) domain with the host cell membrane, consequently leading to membrane fusion and viral RNA release into the host cytosol (Kielian, 2020).

The second SARS-CoV-2 infection mechanism occurs through the endosomal pathway, in a process that depends on phosphatidylinositol-3-phosphate-5-kinase activity, required for the synthesis of phosphatidylinositol-3,5-biphosphate (PI-3,5$\mathrm{P} 2$ ), which is critical for endosome maturation, and on two-pore channel subtype 2 (TPC2), present in late endosomes and lysosomes, which is the main downstream effector of PI-3,5P2, mediating cation transport, mainly $\mathrm{Na}^{+}$and $\mathrm{Ca}^{2+}$ (Ou et al., 2020). Inhibition of the TPC2 activity or PI-3,5-P2 production prevents SARS-CoV-2 endocytosis (Ou et al., 2020). In lysosomes, cysteine proteases (cathepsins $\mathrm{B}$ and $\mathrm{L}$ ) promote $\mathrm{S}$ protein cleavage at the S2' site, allowing the interaction and fusion of the viral envelope and the lysosomal membrane and, consequently, the viral nucleocapsid is released into the host cytosol (Shang et al., 2020).

Any disturbance in the $\mathrm{S}$ protein structure can modulate one or more processes involved in the viral infection and eventually provide some selective advantage for the virus (Harvey et al., 2021). For instance, a specific mutation (or a combination of mutations) in the $S 1$ or $S 2$ subunits can modify: a) the affinity of S1 RBD to ACE2, increasing the virus binding to the host cells; b) the number and exposition of glycosylated sites, facilitating the interaction/accessibility between the viral envelope and host cell plasma membrane; c) the percentage of lying-down and standing-up states of the S1 RBD, elevating the general virus affinity to ACE2; d) the affinity of cleavage sites for proteases, improving the membrane fusion process; and e) recognition by nAbs, reducing the humoral immune response and inducing immune evasion.

The humoral response against SARS-CoV-2 involves specific $n A b s$ against viral epitopes, mainly against the $\mathrm{S}$ glycoprotein $(\mathrm{Ni}$ et al., 2020). Epitopes of the $\mathrm{N}$ protein are highly conserved among different coronaviruses, inducing cross-reacting antibody generation. However, nAbs against the $\mathrm{S}$ protein protect against SARS-CoV-2 infections (Melenotte et al., 2020). Therefore, nAb activity against $S$ glycoprotein allows for the evaluation of the responses induced by vaccines, convalescent plasma, and antibody therapies, as well as the potential immune evasion by different VOCs. The emergence of new variants at the end of 2020 raised new concerns about viral fitness and antibody-based therapies, including vaccines, convalescent sera, and monoclonal antibodies (mAbs) (Fontanet et al., 2021). In addition, new waves of the COVID-19 pandemic have been attributed to the new variants in several parts of the world (Fontanet et al., 2021).

In this review, we address the following critical points concerning SARS-CoV-2 variants: the characteristics of the variants with concerning mutations in the spike gene; the possible evasion of VOCs from nAbs generated through vaccination or previous infection; and perspectives for further studies and actions aimed at preventing or reducing the impact of new VOCs on the COVID-19 pandemic.

\section{SARS-COV-2 SPIKE GENE MUTATIONS}

Several genes of SARS-CoV-2, including $S, N$, and NSP12 (RdRP), present a high mutational range (Focosi and Maggi, 2021). However, compared to other RNA viruses, coronaviruses present a low mutational frequency due to NSP14, which exhibits $3^{\prime}$ to $5^{\prime}$ Exonuclease (ExoN) activity that is critical for high viral replication fidelity (Smith et al., 2014). It has been suggested that other factors can increase the number of mutations in SARSCoV-2.

For example, control measures have had a sizeable negative impact on the economy. Most countries adopted incomplete or insufficient preventive/restrictive measures, with partial participation/adherence, resulting in ineffective control of the COVID-19 pandemic. Consequently, virus transmission and spread increased the probability of new mutations, leading to the emergence of variants with selective advantages (Chen and $\mathrm{Lu}$, 2021). Additionally, individuals with impaired immune competence suffer from prolonged SARS-CoV-2 infections, which increases the likelihood of new mutations (Choi et al., 2020). 
There have also been many SARS-CoV-2 reinfections reported, raising immune pressure and selecting mutations that potentially can help escape immune defense (Abdel-Moneim et al., 2021). Lastly, viral adaptation in susceptible animals and subsequent human infection can produce additional mutations in SARSCoV-2 (Abdel-Moneim et al., 2021).

Mutations can occur in any region of the SARS-CoV-2 genome. Most mutations are silent, meaning that they do not modify the primary amino acid sequence, the function of the translated proteins or viral infectivity. However, a single mutation, or a combination of mutations, can yield variants with selective and survival advantages and improved viral fitness. These mutational variants can present increased infectivity and/ or transmissibility, human ACE-2 receptor binding affinity, viral replication, pathogenicity and reinfection risk. Moreover, depending on the location of the mutation, changes in antigenicity and host-, vaccine- or mAb-induced immune response evasion with alteration in crucial epitopes recognized by nAbs and/or decreased T cell immunity (Dearlove et al., 2020; Abdel-Moneim et al., 2021; Altmann et al., 2021; Callaway and Ledford, 2021; Focosi and Maggi, 2021).

While mutations in other genes could generate variants with enhanced viral infectivity, replication, and immune escape potential (Khateeb et al., 2021; Nguyen et al., 2021), this review will focus on $S$ gene mutations because the spike protein is the most extensively studied viral infection protein and the main protein target for vaccine development. For instance, recent studies have reported that R203K/G204R modifications in the $\mathrm{N}$ protein are associated with high viral replication, infectivity, and transmissibility in cellular and animal models ( $\mathrm{Wu}$ et al., 2021; Zhu et al., 2021b); it has been observed that these modifications appear at a high prevalence in the B.1.1.7 variant (Collier et al., 2021). NSP1 protein is important for suppressing interferon I signaling and increasing viral replication (Xia et al., 2020; Lin et al., 2021). Notably, Lin et al. (2021) observed that a deletion in NSP1 $(\Delta 500-532)$ is related to low plasma IFN- $\beta$ levels and viral load. The high prevalence of the P323L mutation in NSP12 (RdRp) has been implicated in viral replication (Koyama et al., 2020).

Mutations in ORF8 have been suggested to augment viral transmission and immune evasion potential because its gene products participate in the RNA polymerase complex and are involved in controlling the host cells' major histocompatibility complex class I (Young et al., 2020; Flower et al., 2021; Pereira, 2021). Pereira (2021) observed a high prevalence of a premature stop codon at position 27 in ORF8 (Q27stop) that occurs in the B.1.1.7 variant, potentially contributing to its high transmission rate and spread.

Emerging variants can be considered a variant under investigation (VUI), a variant of interest (VOI), or a variant of concern (VOC). The WHO has recognized several VOIs, including B.1.427 and B.1.429 from the USA (California, WHO alert since July 6, 2021), B.1.525 from the United Kingdom and Nigeria, B.1.526 from the USA (New York), B.1.617.1 and B.1.617.3 from India, P2 from Brazil, and C.37 from Peru. Furthermore, the WHO has classified five variants as
VOCs: B.1.1.7 from the United Kingdom (501Y. V1, VOC 202012/01, alpha variant), B.1.351 from South Africa (501Y. V2, VOC 202012/02, beta variant), P.1 from Brazil (501Y. V3, VOC 202101/02, gamma variant); B.1.617.2 from India (VOC 202104/02, delta), and B.1.1.529 from multiple countries (omicron variant). Notably, the B.1.617.2 variant was linked to the fast spread of SARS-CoV-2 in several countries (Adam, 2021).

The D614G mutant in the $S$ gene, first identified in Europe in January 2020, was one of the first SARS-CoV-2 mutations to spread worldwide (Conti et al., 2021; Dearlove et al., 2020). This mutation is positioned between the S1 and S2 subunits (Dearlove et al., 2020) and has been reported to increase in vitro viral infectivity (Dearlove et al., 2020; Korber et al., 2020; Groves et al., 2021), affinity binding to the ACE-2 receptor and transmissibility (Volz et al., 2020; Ozono et al., 2021), protease-induced S protein cleavage (Gobeil et al., 2021), replication, and viral loads (AbdelMoneim et al., 2021). Despite the apparently enhanced "viral fitness" (Dearlove et al., 2020; Plante et al., 2020) and its ability to neutralize the activity of antibodies induced by previous infections or vaccines (Dearlove et al., 2020; Groves et al., 2021), the clinical outcomes or pathogenicity remain unchanged (Volz et al., 2020; Groves et al., 2021). It has been proposed that the $\mathrm{D} 614 \mathrm{G}$ mutation causes the ACE-2 receptor to assume "open conformation", increasing the binding affinity (Yurkovetskiy et al., 2020) and the virus's susceptibility to nAbs (Garcia-Beltran et al., 2021a).

The B.1.1.298 variant (mink Cluster 5) was one of the first to contain the D614G mutation. This variant was associated with an outbreak on Denmark mink farms (Oude Munnink et al., 2021), resulting in 17 million Danish minks being culled as a preventive measure to stop virus evolution and spread (Garcia-Beltran et al., 2021b). It has been suggested that other modifications, including $\mathrm{Y} 453 \mathrm{~F}$ in the RBD of the S protein, P323L in NSP12 (a component of RdRp), and R203K and G204R in the N protein, also contributed to the improved viral fitness of the B.1.298 variant (Plante et al., 2021). Notably, the D614G mutation has become more predominant, appearing in all recently identified variants.

The first VOC described (VOC 202012/01) was the B.1.1.7 lineage (20I/501Y. V1), identified in the United Kingdom (Sep 2020). This variant is now present on all continents. In December 2020, B.1.1.7 was responsible for one-quarter of the total COVID-19 cases worldwide and two-thirds of the cases in the United Kingdom (Conti et al., 2021). Compared to the original virus, B.1.1.7 exhibits a $40-70 \%$ increase in transmissibility (Graham et al., 2021; Volz et al., 2021). The B.1.1.7 lineage has 23 mutations in the $S, N$, and ORF-8 genes, but the impact of each mutation on viral fitness and survival or vaccine efficacy is not completely known (Conti et al., 2021; Focosi and Maggi, 2021).

The $\mathrm{S}$ protein of the B.1.1.7 lineage contains several amino acid mutations, including D614G and N501Y, and deletions $\Delta \mathrm{H} 69 / \Delta$ V70 (Focosi and Maggi, 2021). The S RBD N501Y mutation increases the binding affinity to the ACE-2 receptor and transmissibility (Starr et al., 2020; Graham et al., 2021; 
Focosi and Maggi, 2021). Gu et al. (2020) developed a mouseadapted strain model (MASCp6) to evaluate the SARS-CoV-2 infectivity and virulence after intranasal inoculation and observed that the N501Y mutation favors interaction with ACE2 and promotes virus entry, consequently leading to enhanced virulence. Recent studies have suggested that the N501Y mutation has a low impact on clinical outcomes and pathogenicity (Conti et al., 2021; Graham et al., 2021) and the immune response generated by mAbs, vaccines, or previous infection (Muik et al., 2021; Focosi and Maggi, 2021). However, Davies et al. (2021) evaluated more than 2.2 million people with SARS-CoV-2 positive tests and 17,452 related deaths in England and observed a 61\% higher risk of death risk in those infected with the B.1.1.7 variant than other pre-existing variants. Thus, the B.1.1.7 variant presents increased transmissibility and disease severity.

The B.1.351 lineage (20H/501Y. V2, VOC 202012/02) emerged in South Africa (Oct 2020), probably favored by the high immune pressure, and spread to other African countries, Asia, Australia, and North and Central America (Focosi and Maggi, 2021). By the end of 2020, this variant was responsible for more than $90 \%$ of all COVID-19 cases in South Africa (Callaway and Mallapaty, 2021). This lineage has several structural and nonstructural mutations, including three critical mutations in the RBD of the S protein (K417N, E484K, and N501Y) that seem to play a crucial role in the improved "viral fitness" and survival adaptations compared to the other strains in some regions where it was prevalent (Focosi and Maggi, 2021). The K417N mutation exacerbated immune escape from $\mathrm{nAbs}$ and reduced vaccine effectivity against infection (Callaway and Mallapaty, 2021; Focosi and Maggi, 2021), and the E484K modification is associated with increased binding to the ACE-2 receptor (Focosi and Maggi, 2021) and a decreased or even abrogated response to $\mathrm{Ab}$ neutralization induced by previous infection, vaccination, or monoclonal Ab therapy (Liu Z. et al., 2021). Furthermore, five mutations in the NTD of the $S$ gene were proposed to contribute to improved viral microenvironment adaptations (Li et al., 2021). This lineage is also associated with increased spreading (Garcia-Beltran et al., 2021a) and reinfection cases in subjects previously infected with the original SARSCoV-2 (Staub et al., 2021).

In December 2020, the P.1 lineage (20J/501Y. V3, VOC 202101/02, also called P.1) accounted for $42 \%$ of the total cases in Manaus, Brazil (Chen and Lu, 2021), and in February 2021, it was discovered in Japan in samples from individuals traveling from Manaus. The three main mutations are the same as in B.1.351: K417T, E484K, and N501Y (Focosi and Maggi, 2021). This lineage has increased ACE-2 receptor binding affinity, transmissibility (Focosi and Maggi, 2021; Francisco et al., 2021), infectivity in mice (Chen and $\mathrm{Lu}, 2021$ ), resistance to immune response (Focosi and Maggi, 2021; Francisco et al., 2021), and risk of reinfection (Chen and Lu, 2021; Taylor, 2021; Sabino et al., 2021). The main similarities and differences among B.1.1.7, B.1.351, and P.1 are summarized in Figure 2. Similar and differential mutations of the main SARS-CoV-2 variants are shown in Figure 3.

The B.1.617 lineage contains three sublineages: B.1.617.1, B.617.2 (delta variant), and B.1.617.3. B1.617.2 exhibits higher transmissibility than the ancestral strain, and studies suggest a high risk of hospitalization compared to the original strain or the B.1.1.7 variant (Liu and Rocklöv, 2021; Ong et al., 2021; Sheikh et al., 2021). In a short review, Liu and Rocklöv (2021) reported a

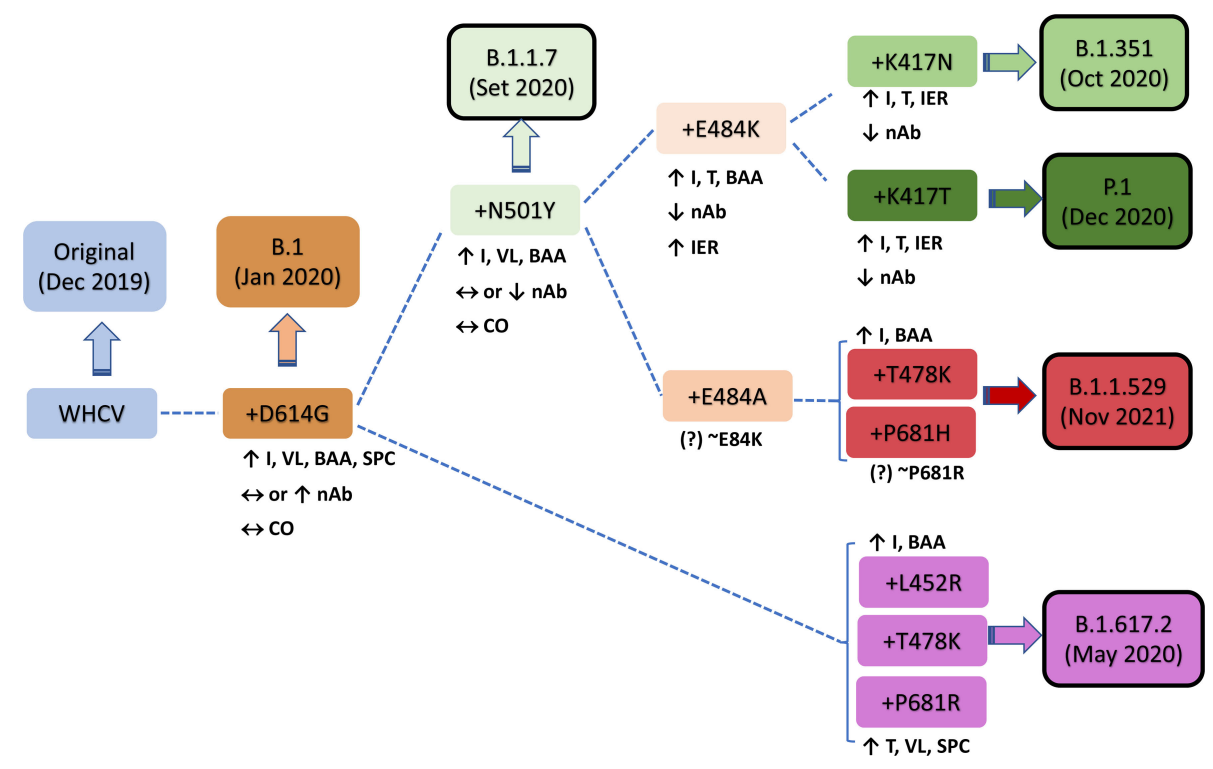

FIGURE 2 | Characteristics of key mutations in variants of concern (VOCs). A comparison was performed versus the original virus (WHCV) or the B.1 strain (+D614G). BAA, binding affinity to ACE2; CO, clinical outcome; I, infectivity; IER, immune evasion risk; nAb, neutralizing antibody; SPC, spike protein cleavage; T, transmissibility; VL, viral load; WHCV, WH-Human 1 coronavirus. 


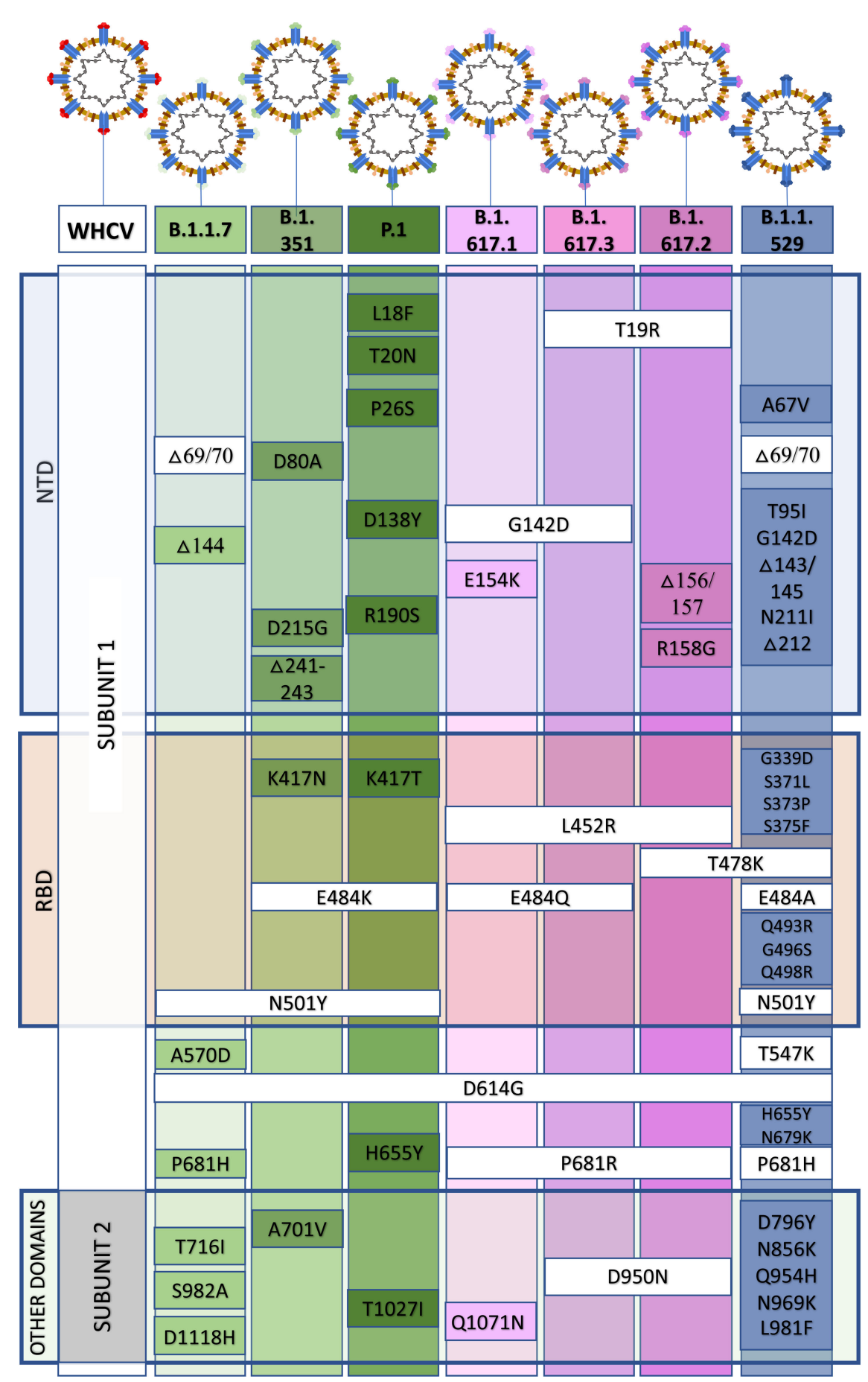

FIGURE 3 | Similar and differential mutations in the spike (S) protein from the B.1.1.7, B.1.351, P.1, B.1.617, and B.1.1.529 variants of concern. NTD, N terminal domain; RBD, receptor-binding domain.

basic reproductive number $\left(R_{0}\right)$ of 5.08 for the delta variant versus 2.79 for the ancestral SARS-CoV-2 strain. Since no difference was observed in the median age and disease duration between patients infected with B.1.617.2 or nonB.1.617.2 strains (Mlcochova et al., 2021), the elevated risk of hospitalization is probably due to the high transmissibility of the B.1.627.2 variant compared to other strains. Most fully vaccinated people are protected against the B.1.617 variants (Lopez Bernal et al., 2021). However, even after full vaccination, people can be infected by B.1.617.2 or other 
variants and transmit them to others, albeit with a lower risk of disease severity and shorter infection period than unvaccinated individuals (Ong et al., 2021; Sheikh et al., 2021). Notable mutations in the B.1.617.2 variant include L452R, T478K and E484Q in the S RBD and P681R in the cleavage site between S1 and S2.

The L452R mutation appears to increase the interaction between RBD and the ACE-2 and infectivity (Kirola, 2021). Moreover, the T478K mutation, together with L452R, helps stabilize the RBD-ACE-2 complex and elevate the virus infectivity rate (Cherian et al., 2021). The E484Q mutation enhances binding affinity to ACE-2 and potentially reduces antibody binding affinity, an observation similar to the E484K mutation (Kirola, 2021). In addition, the P681R mutation, located at the cleavage site between S1 and S2, has been associated with augmented transmissibility and viral load (Lopez Bernal et al., 2021). In a preprint work, Liu et al. (bioRxiv [Preprint]. 2021 Sep 5:2021.08.12.456173) observed that P681R modification leads to the increased furin cleavage site (S1-S2 junction), resulting in higher infectivity than the B.1.1.7 strain. The combination of mutations in the B.1.617.2 variant (delta variant) seems to impart the virus a selective advantage compared to the original virus and other variants, as evidenced by high transmissibility and infectivity, and potential immune evasion (Cherian et al., 2021; Kirola, 2021; Lopez Bernal et al., 2021).

Recently, an emerging SARS-CoV-2 variant was initially identified in South Africa, but it has been simultaneously detected in several other countries. On November 26, 2021, the WHO classified this variant as a VOC (B.1.1.529, omicron variant) because of the alarming epidemiological situation in South Africa (Callaway, 2021). The B.1.1.529 variant contains several mutations present in other variants, such as N501Y (alpha), E484A E484K (beta and gamma), and T478K; $\mathrm{P} 681 \mathrm{H} \sim \mathrm{P} 681 \mathrm{R}$ (delta). As discussed above, several of these changes observed in alpha, beta, and delta have been related to enhanced infectivity, transmissibility, and potential immune escape. However, it remains unclear whether or not the similarities with previous VOCs are related to the omicron variant's rapid spread. In total, the B.1.1.529 (omicron) variant has more than 50 mutations, with more than 30 in the $S$ gene alone (Callaway, 2021; GISAID, 2021). In addition, Wang and Cheng (2021) have identified potential mutations that can affect ACE2 and/or antibody binding. Omicron variant accumulates numerous mutations, including Q498R and S477N, which have been previously associated with elevated binding to ACE2 receptor, potentially enhancing viral infectivity to the host cells. Recently, it was observed a close connection between Omicron and the Alpha variants, suggesting that the omicron variant was circulating for an long period before its discovery (Kandeel et al., 2021). Ongoing research is trying to elucidate the role and effect of each mutation in the omicron variant. Currently, it appears as though the omicron variant does not increase disease severity or fatality (hospitalization and number of deaths), and there is no evidence of immune escape from approved vaccines.
In South Africa, the emergence of the omicron variant rapidly and concomitantly increased the number of daily cases from 273 cases/day on November 16 to more than 1,200 cases/day on November 25. Additionally, as of December 9, 2021, the omicron variant was confirmed in 63 countries in Africa, Europe, Australia, Asia and North, Central and South America (GISAID, 2021; Torjesen, 2021).

\section{EFFICACY AND ANTIBODY NEUTRALIZATION ACTIVITY OF VACCINES AGAINST SARS-COV-2 VARIANTS}

Most COVID-19 vaccines use the S protein as the primary target, aiming to produce $\mathrm{nAbs}$ against the $\mathrm{RBM}$ regions, block the viral binding sites to the ACE-2 receptor in the host cells, and prevent infection (Chen R. E. et al., 2021). Since the first generation of vaccines was developed based on the original SARS-CoV-2 without $S$ protein amino acid mutations (Chen R. E. et al., 2021; Dearlove et al., 2020), medical professionals now face the challenge of determining if the efficacy of these vaccines against the new variants is preserved or impaired (Chen R. E. et al., 2021; Dearlove et al., 2020). Presently, most approved COVID-19 vaccines protect against the described VOCs; however, constant surveillance and new studies about vaccine efficacies against the current VOCs and future SARS-CoV-2 variants globally are critical. It is also important to point out that most studies concerning nAbs activity were performed using SARSCoV-2 pseudoviruses, which may not reflect the virus's behavior in the real world. Furthermore, a reduction in nAb activity does not necessarily result in poor vaccine efficacy or effectiveness, as demonstrated by several recent studies.

For example, the mRNA-based BNT 162b2 vaccine (Pfizer/ BioNTech) reached $95 \%$ efficacy against the original SARS-CoV-2 infection (Polack et al., 2020). Notably, using immune sera from vaccinated subjects, no difference (Kuzmina et al., 2021) or mild to moderately decreased $\mathrm{nAb}$ activity (1.7 to 6.0 -fold) against the B.1.1.7 pseudovirus has been described (Collier et al., 2021; Hoffmann et al., 2021; Lustig et al., 2021; Muik et al., 2021; Supasa et al., 2021). Thus, this variant probably does not increase immune escape or attenuate vaccine efficacy (Muik et al., 2021; Supasa et al., 2021). In contrast, the nAb activity provided by the BNT 162b2 vaccine was significantly reduced (6.5 to 10.4 -fold) or abrogated against the B.1.351 pseudovirus (Chen R. E. et al., 2021; Dejnirattisai et al., 2021; Hoffmann et al., 2021; Kuzmina et al., 2021; Lustig et al., 2021; Zhou et al., 2021). Additionally, a reduction of 2.1 to 5.1-fold and 1.4 to 3.0-fold in $\mathrm{nAb}$ activity was reported for the P.1 and B.1.617.2 variants, using the serum from vaccinated individuals (Dejnirattisai et al., 2021; Hoffmann et al., 2021; Liu J. et al., 2021; Lustig et al., 2021; Planas et al., 2021).

BNT 162b2 vaccine effectiveness was also evaluated in the Qatar population, when the B.1.1.7 and B.1.351 variants accounted for $50 \%$ and $44.5 \%$ of the total COVID-19 cases from February to March 2021 (Abu-Raddad et al., 2021). A mass vaccination campaign was performed in the country, with 
385,853 people receiving one dose and 265,410 receiving two doses of the vaccine by the end of March 2021 (Abu-Raddad et al., 2021). After 14 days or more after the second dose of the BNT 162b2 vaccine, the effectiveness against B.1.1.7 variant infection was $89.5 \%$, and $75.0 \%$ against B.1.351. Moreover, the vaccine's effectiveness against severe COVID-19 cases or death was $97.4 \%$ against both variants (Abu-Raddad et al., 2021). In another real-world study performed in Qatar between December 2020 and September 2021, 950,232 people received at least one dose and 916,290 people two doses of the BNT162b2 vaccine (with an average of 21 days between doses) (Tang et al., 2021). The authors observed similar results against infection (74.3\%) and severe/critical/fatal disease (92.7\%) caused by B.1.351 variant and low effectiveness against B.1.617.2 infection (51.9\%). Despite the reduced protection against infection, the vaccine was still highly effective against severe/critical/fatal disease (93.4\%) caused by the B.1.617.2 variant.

Another mRNA-based vaccine, the mRNA-1273 vaccine (Moderna), also reached a high global efficacy of $94 \%$ and induced $\mathrm{nAb}$ production (Baden et al., 2021). Against the B.1.1.7 pseudovirus, no difference or a modest reduction in nAb activity was reported (Shen et al., 2021; Wu et al., 2021). On the other hand, a pronounced reduction in $\mathrm{nAb}$ activity (6.4fold) against the B.1.351 variant was observed (Wu et al., 2021). Another study demonstrated that IgG antibody binding and neutralization activity are moderately impaired against the B.1.351 variant, but this vaccine is still efficient/effective against this variant (Edara et al., 2021b). Compared to B.1.351, the reduction in $\mathrm{nAB}$ activity was less pronounced in the P.1 and B.1.427/429 variants (Wu et al., 2021). The mRNA-1273 vaccine also exhibited reduced $\mathrm{nAb}$ activity (2.1 to 3.3 -fold) against B.1.617.2 compared to the D614G strain (Choi et al., 2021). In the real-world study performed in Qatar described above (Tang et al., 2021), 564,468 people received at least one dose, and 509,322 received two doses of the mRNA-1273 vaccine (with an average of 28 days between doses). The authors reported $80.8 \%$ effectiveness against infection and $100 \%$ against severe, critical, or fatal disease caused by B.1.351 and $73.1 \%$ effectiveness against infection and $96.1 \%$ against severe, critical, or fatal disease caused by B.1.167.2 variant.

The recombinant spike protein-based NVX-CoV2373 vaccine (Novavax) presents an efficacy of $95.6 \%$ against the original SARS-CoV-2 strain (Callaway and Mallapaty, 2021; Moore and Offit, 2021). Against the B.1.1.7 pseudovirus, this vaccine has a low reduction in $\mathrm{nAb}$ activity (Shen et al., 2021), which is followed by a modest decrease in efficacy (85.6\%) (Shen et al., 2021). In a South African phase $2 \mathrm{a} / \mathrm{b}$ clinical trial, vaccine efficacy against mild to moderate disease was significantly reduced (49.4\%) in a population of 4,387 participants when the B.1.351 variant was predominant $(92.7 \%)$ (Shinde et al., 2021). In another study performed in South Africa, when more than $90 \%$ of the total COVID-19 cases were due to the B.1.351 variant (i.e., end of 2020 and the beginning of 2021), the vaccine reached an efficacy of $60 \%$ (https://www.novavax.com/ sites/default/files/2021-02/20210202-NYAS-Novavax-Final.pdf). Currently, the B.1.617.2 variant is predominant in South Africa and worldwide, and data regarding effectiveness against this variant is crucial for understanding the real protection elicited by the Novavax vaccine.

The adenovirus vector-based ChAOx1-nCoV-19 vaccine (University of Oxford/AstraZeneca) was shown to have $66.7 \%$ efficacy against SARS-CoV-2 infection (Voysey et al., 2020). Against the B.1.1.7 pseudovirus vaccinee sera display reduced (9-fold and 2.5-fold) nAb activity without affecting vaccine efficacy $(74.6 \%)$ in 499 infected people with the variant (Zhou et al., 2021; Supasa et al., 2021). Similar results were reported in another study comparing B.1.1.7 and non-B.1.1.7 lineages, with $70.4 \%$ and $81.5 \%$ efficacy against infection, respectively (Emary et al., 2021). For the B.1.351 lineage, the ChAOx-1nCoV-19 vaccine elicits less potent $\mathrm{nAb}$ production against the B.1.351 pseudovirus. B.1.351 is mainly characterized by the triple mutations in the RBD of the $S$ protein and associated with reduced $\mathrm{nAb}$ titers (9-fold) and global efficacy against infection (10.4-20.4\%) and impaired efficacy $(21.9 \%)$ to prevent mild to moderate COVID-19 (Dejnirattisai et al., 2021; Madhi et al., 2021; Planas et al., 2021; Zhou et al., 2021). A small reduction in $\mathrm{nAb}$ activity was also reported for the P.1 (2.9-fold) and B.1.617.2 variants (5.0-fold) (Dejnirattisai et al., 2021; Planas et al., 2021). Notably, the real-world effectiveness against B.1.617.2 infection (67\%) was similar to the wild-type (66.7\%) and B.1.1.7 (74.6\%) strains (Lopez Bernal et al., 2021).

The Ad26.COV2. S or JNJ-78436735 vaccine (Janssen), another adenovirus vector-based vaccine, has an efficacy of $72 \%$ against B.1.1.7 infection. The vaccine's efficacy is reduced to $57 \%$ against the B.1.351 variant but is $89 \%$ effective at protecting against severe COVID-19 (https://www.jnj.com/ johnson-johnson-announces-single-shot-janssen-covid-19vaccine-candidate-met-primary-endpoints-in-interim-analysisof-its-phase-3-ensemble-trial).

The vector-based Sputnik V vaccine or Gam-COVID-Vac (Gamaleya Institute) (Moore and Offit, 2021) presents 91.6\% efficacy against SARS-CoV-2 infection (Logunov et al., 2021). However, the efficacies against B.1.1.7, B.1.351, and P.1 were reduced to $81 \%, 59 \%$, and $52 \%$, respectively. The serum nAb activity was not significantly altered against B.1.1.7 but was decreased against the B.1.1.351 (3.1-fold), P.1 (2.8-fold), and B.1.617.2 (2.5-fold) variants (Gushchin et al., 2021).

The Sinopharm and CoronaVac vaccines use inactivated virus-based technology. The CoronaVac vaccine was shown to be $83.5 \%$ (Tanriover et al., 2021) and $65.9 \%$ effective in studies conducted in Turkey and Chile, respectively (Jara et al., 2021). It was also demonstrated that $\mathrm{nAb}$ activity was unaffected against B.1.429 but was decreased against the B.1.1.7, B.1.351, and P.1 variants by 2.0, 5.2, and 3.9-fold, respectively (Chen Y. et al., 2021; Wang et al., 2021). For the Sinopharm vaccine, nAb activity was reduced against the B.1.1.7 ( 2.0-fold) and B.1.351 (2.5 to 3.0-fold) variants (Wang et al., 2021).

More results related to the B.1.617.2 variant are necessary for all these vaccines to verify the real-world effectiveness against infection and severe or critical COVID-19 disease. Furthermore, a thorough analysis of this variant's potential immune response evasion in vaccinated individuals must be conducted. In relation 
to omicron variant, there are some preliminary results from few studies with limited sample size suggesting that the incidence of virus reinfection in South Africa can be associated with humoral (antibody-mediated) immune evasion and $\mathrm{nAb}$ activity in vaccinated or previously infected individuals (Zhang et al., 2021).

Besides vaccines, convalescent sera have been used to evaluate the impact of variants on the $\mathrm{nAb}$ activity induced by the previous infection with the original SARS-CoV-2. Several studies observed a mild reduction ( 2.9 to 3.0-fold) in $\mathrm{nAb}$ activity against the B.1.1.7 variant (Dejnirattisai et al., 2021; Supasa et al., 2021; Zhou et al., 2021). Partial (11 to $33 \mathrm{X}$ ). Variants containing the E484K mutation (e.g., B.1.351 and B.1.1.248 variants) were found to escape the immune response completely (Chen R. E. et al., 2021; Kuzmina et al., 2021; Zhou et al., 2021;14). Additionally, convalescent sera of individuals infected with the original SARS-CoV-2 displayed impaired or nonexistent IgG antibody binding and neutralization activity against the B.1.351 variant (4 to 8-fold; 13.3-fold) (Dejnirattisai et al., 2021; Edara et al., 2021a), persisting eight months postinfection (2.1-fold) (Edara et al., 2021b). Indeed, it has been estimated that 41.1 to $48 \%$ of convalescent sera are incapable of neutralizing the B.1.351 pseudovirus (Zhou et al., 2021; Wibmer et al., 2021). Furthermore, a similar reduction in nAb activity was observed against the P.1 and B.1.1.7 variants (3.1 and 2.9-fold, respectively) (Dejnirattisai et al., 2021).

A summary of the efficacy and $\mathrm{nAb}$ activity of the main vaccines against SARS-CoV-2 variants is presented in Table 1. In Table 2, we have provided the details of the protocols used in the studies.

\section{VARIANTS OF CONCERN AND POTENTIAL RISK OF NEW PANDEMIC WAVES}

From December 2019 until December $16^{\text {th }} 2021$, there have been more than 271,376,000 COVID-19 cases and 5,325,969 COVID- 19-related deaths (1.96\% mortality rate) worldwide (World Health Organization, https://covid19.who.int). Moreover, approximately 3.4 million SARS-CoV-2 genome sequences have been submitted to the Global Initiative on Sharing All Influenza Data (GISAID; https://gisaid.org), which has detected more than 4,100 mutations in the $S$ gene. About 1,200 of these mutations lead to amino acid substitutions, with 187 in the RBD of the S protein (Focosi and Maggi, 2021; Liu C. et al., 2021).

We performed a monthly analysis of the VOC emergence using the GISAID in several countries for one year (September 2020 to November 2021). The analysis of the epidemiological data of SARS-CoV-2 variants has several limitations, including a) a limited number of genome sequencing data from a particular country; b) samples from a particular group, city, or region that does not accurately represent the country; c) the virus' behavior in a specific group, city or region; and d) data release delay (data were extracted and analyzed on September 2, 2021, but new sequencing genomes are continuously submitted and updated, especially in the last few months). However, it provides a general overview of specific variants globally and highlights some important points.

For example, after the emergence of the B.1.1.7 variant in the United Kingdom (September 2020), it rapidly spread to several countries across all continents (169 countries on Sep 2, 2021). In 34 of the 67 countries analyzed, the B.1.1.7 variant became highly predominant, present at rates greater than $80 \%$; thus, demonstrating a clear selective advantage of this variant versus the original B.1 strain, which was the most prevalent strain at that moment in time (Figure 4). Additionally, in 12 of the 67 countries, this VOC was detected in 50.1 to $80 \%$ of the new monthly cases. In some countries, where other VOCs emerged before or even simultaneously, as in the case of B.1.351 in South Africa and Reunion and P.1 in Brazil, Chile, and French Guiana, the B.1.1.7 variant did not become predominant. This observation suggests that B.1.1.7 has no selective advantage over the B.1.351 and P.1 VOCs.

The B.1.351 variant emerged in South Africa in August 2020 and rapidly disseminated worldwide, reaching 111 countries as

TABLE 1 | VOCs and vaccine-induced immune response resistance.

\begin{tabular}{|c|c|c|c|c|c|c|}
\hline VOCs & & WHCV (Wuhan/China) & B.1.1.7 UK & B.1.351 South Africa & P.1 Brazil & B.1.617.2 India \\
\hline \multirow[t]{2}{*}{ Pfizer } & Efficacy & $90.4-95.5 \%$ & $89.5-93.7 \%{ }^{*}$ & $75.0 * \%$ & N.D. & $70-88 \%{ }^{*}$ \\
\hline & NABs & - & $\downarrow 0-3.3 x$ & $\downarrow 3.3-16 X$ & $\downarrow 2.2-6.7 X$ & $\downarrow 2.1-3.3 X$ \\
\hline \multirow[t]{2}{*}{ Moderna } & Efficacy & $94.1 \%$ & $\sim$ & N.D. & N.D. & N.D. \\
\hline & NABs & - & $\downarrow 0-2.3 \times$ & $\downarrow 3-9 x$ & $\downarrow 3.5-4.5 X$ & $\downarrow 3 x$ \\
\hline \multirow[t]{2}{*}{ AstraZeneca } & Efficacy & $54-79 \%$ & $70.4-74.5 \%{ }^{*}$ & $10.4 \%$ & N.D. & $67-77.3 \%{ }^{*}$ \\
\hline & NABs & - & $\downarrow 0-2.5 \times$ & $\downarrow 9 x$ & $\downarrow 2.8-2.9 \times$ & $\downarrow 4.2-5 x$ \\
\hline \multirow[t]{2}{*}{ Novavax } & Efficacy & 89.3-95.6\% & $85.6 \%$ & $49.4-60 \%$ & N.D. & N.D. \\
\hline & NABs & - & $\downarrow 2 X$ & & & \\
\hline \multirow[t]{2}{*}{ Janssen } & Efficacy & $66 \%$ & $72 \%$ & $57 \%$ & $68.1 \%$ & N.D. \\
\hline & NABs & - & $\downarrow 2.8-3.3 \times$ & $\downarrow 5-10.6 x$ & $\downarrow 3.3 x$ & \\
\hline \multirow[t]{2}{*}{ Sputnik V } & Efficacy & $91.6 \%$ & $81 \%$ & $59 \%$ & $52 \%$ & N.D. \\
\hline & NABs & - & $\downarrow 0 x$ & $\downarrow 3.1-3.5 \times$ & $\downarrow 2.8 X$ & $\downarrow 2.5 \times$ \\
\hline \multirow[t]{2}{*}{ Sinovac } & Efficacy & $65.9^{\star}-83.5 \%$ & N.D. & $50 \%$ & N.D. & N.D. \\
\hline & NABs & - & $\downarrow 0-2.0 x$ & $\downarrow 2.5-5.2 X$ & $\downarrow 3.9 X$ & \\
\hline \multirow[t]{2}{*}{ Sinopharm } & Efficacy & $79.0-86 \%$ & N.D. & N.D. & N.D. & N.D. \\
\hline & NABs & - & $\downarrow 0-2.0 \times$ & $\downarrow 2.5-3.0 x$ & & \\
\hline
\end{tabular}

NABs, neutralizing antibodies; N.D., not determined or under investigation; VOC, variant of concern; *: effectiveness evaluation instead efficacy analysis. 
TABLE 2 | Studies about efficacy/effectiveness and neutralizing antibody activity of vaccines and convalescent plasma against SARS-CoV-2 variants.

\begin{tabular}{|c|c|c|c|c|}
\hline Study & $\begin{array}{l}\text { Vaccine or } \\
\text { plasma }\end{array}$ & Sample size & Methodology & Main findings \\
\hline $\begin{array}{l}\text { Abu- } \\
\text { Raddad } \\
\text { et al., } 2021\end{array}$ & BNT 162b2 & $\begin{array}{l}>383,000 \text { individuals with at least } 1 \text { dose } \\
\text { and }>265,000 \text { with } 2 \text { doses; analysis }>14 d \\
\text { after the } 2 \text { nd dose }\end{array}$ & $\begin{array}{l}\text { Effectiveness in a mass immunization campaign and virus } \\
\text { sequencing of positive cases in Qatar }\end{array}$ & $\begin{array}{l}\text { 89.5\% against B.1.1.7; } \\
\text { 75.0\% against B.1.351; } \\
\text { 97.4\% against severe } \\
\text { disease }\end{array}$ \\
\hline $\begin{array}{l}\text { Alter et al., } \\
2021\end{array}$ & Ad6.COV2.S & $\begin{array}{l}25 \text { adults at different vaccination regimens } \\
\text { (14 d after the last dose) }\end{array}$ & $\begin{array}{l}\text { Luciferase-based pseudovirus neutralizing antibody (psVNA) } \\
\text { assay against WA1/2020, D614G, B.1.1.7, B.1.351, and P.1 }\end{array}$ & $\begin{array}{l}\downarrow 2.8,5-10.6 \text {, and } 3.3 \mathrm{X} \text { in } \\
\text { neutralizing B.1.1.7, } \\
\text { B.1.351, and P.1 variants, } \\
\text { respectively }\end{array}$ \\
\hline $\begin{array}{l}\text { Lopez } \\
\text { Bernal } \\
\text { et al., } 2021\end{array}$ & ChAdOx1-S & $\begin{array}{l}\text { 171,834 individuals: } 96,371 \text { unvaccinated; } \\
51,470 \text { vaccinated with } 1 \text { dose (analysis at } \\
>21 \text { d); and 23,993 with } 2 \text { doses (analysis at } \\
>14 \text { d) }\end{array}$ & $\begin{array}{l}\text { Effectiveness by a test negative casecontrol design study and } \\
\text { whole-genome sequencing in England }\end{array}$ & $\begin{array}{l}1 \text { dose: } 47.5 \% \text { for B.1.1.7 } \\
\text { and } 35.6 \% \text { for B.1.617.2 } \\
2 \text { doses: } 93.7 \% \text { for B.1.1.7 } \\
\text { and } 88 \% \text { for B.1.617.2 } \\
1 \text { dose: } 48.7 \% \text { for B.1.1.7 } \\
\text { and } 30 \% \text { for B.1.617.2 } \\
2 \text { doses: } 74.5 \% \text { for B.1.1.7 } \\
\text { and } 67 \% \text { for B.1.617.2 }\end{array}$ \\
\hline \multirow[t]{2}{*}{$\begin{array}{l}\text { Chen R. E. } \\
\text { et al., } 2021\end{array}$} & BNT 162b2 & $\begin{array}{l}10 \text { vaccinee serum (one week after the } 2 \text { nd } \\
\text { dose) }\end{array}$ & $\begin{array}{l}\text { FRNT using D614G wild-type, B.1.1.7, B.1.351, and B1.1.28 } \\
\text { strains }\end{array}$ & $\begin{array}{l}\downarrow 2,10 \text {, and } 2.2 X \text { in } \\
\text { neutralizing B.1.1.7, } \\
\text { B.1.351, and P.1 }\end{array}$ \\
\hline & $\begin{array}{l}\text { Convalescent } \\
\text { plasma }\end{array}$ & $\begin{array}{l}10 \text { convalesdent plasma ( } 30 \mathrm{~d} \text { after } \\
\text { infection) }\end{array}$ & & $\downarrow 2.5 X$ in neutralizing P.1 \\
\hline $\begin{array}{l}\text { Chen } Y . \\
\text { et al., } 2021\end{array}$ & CoronaVac & 93 vaccinee serum (14 d after the 2 nd dose) & $\begin{array}{l}\text { Pseudovirus neutralization against different strains (Wuhan-1 } \\
\text { wild-type, D614G, B.1.1.7, B.1.351, and P.1) }\end{array}$ & $\begin{array}{l}\downarrow 0,5.2 \text {, and } 3.9 \times \text { in } \\
\text { neutralizing B.1.1.7, } \\
\text { B.1.351, and P.1 }\end{array}$ \\
\hline $\begin{array}{l}\text { Choi et al., } \\
2021\end{array}$ & mRNA-1273 & 8 vaccinee serum (7 d after the 2 nd dose) & $\begin{array}{l}\text { Pseudovirus neutralization against different strains (D614G, } \\
\text { B.1.1.7, B.1.351, P.1, and B.1.617.2) }\end{array}$ & $\begin{array}{l}\downarrow 1.2,6.9-8.4,3.2 \text {, and } \\
2.1-3.3 \mathrm{X} \text { in neutralizing } \\
\text { B.1.1.7, B.1.351, P.1, and } \\
\text { B.1.617.2 }\end{array}$ \\
\hline \multirow[t]{2}{*}{$\begin{array}{l}\text { Collier } \\
\text { et al., } 2021\end{array}$} & BNT 162b2 & $\begin{array}{l}25 \text { vaccinee serum ( } 3 \text { wks after the } 2 \text { nd } \\
\text { dose) }\end{array}$ & $\begin{array}{l}\text { Pseudovirus neutralization against D614G strain and B.1.1.7 } \\
\text { variant }\end{array}$ & $\begin{array}{l}\downarrow 1.9 \times \text { in neutralizing } \\
\text { B.1.1.7 }\end{array}$ \\
\hline & $\begin{array}{l}\text { Convalescent } \\
\text { plasma }\end{array}$ & 27 convalesdent plasma & & $\begin{array}{l}\downarrow 4.5 \times \text { in neutralizing } \\
\text { B.1.1.7 }\end{array}$ \\
\hline \multirow[t]{4}{*}{$\begin{array}{l}\text { Dejnirattisai } \\
\text { et al., } 2021\end{array}$} & BNT 162b2 & $\begin{array}{l}25 \text { vaccinee serum ( } 4-14 d \text { after the } 2 \text { nd } \\
\text { dose) }\end{array}$ & FRNT using Victoria and B.1.351 strains & $\begin{array}{l}\downarrow 3.3,7.6 \text {, and } 2.6 \mathrm{X} \text { in } \\
\text { neutralizing B.1.1.7, } \\
\text { B.1.351, and P.1 }\end{array}$ \\
\hline & AZD1222 & 25 vaccinee serum $(14-2$ & & $\begin{array}{l}\downarrow 2.5,9 \text {, and } 2.9 \times \text { in } \\
\text { neutralizing B.1.1.7, } \\
\text { B.1.351, and P.1 }\end{array}$ \\
\hline & $\begin{array}{l}\text { Convalescent } \\
\text { plasma }\end{array}$ & $\begin{array}{l}34 \text { convalesdent plasma ( } 4 \text { - } 9 \text { mo after } \\
\text { infection) }\end{array}$ & & $\begin{array}{l}\downarrow 2.9,13.3 \text {, and } 3.1 \mathrm{X} \text { in } \\
\text { neutralizing B.1.1.7, } \\
\text { B.1.351, and P.1 }\end{array}$ \\
\hline & BNT162b2 & 10 participants (7-27 d ater the 2nd dose) & & $\begin{array}{l}\downarrow 3.3 X \text { in neutralizing } \\
\text { B.1.617.2 }\end{array}$ \\
\hline \multirow[t]{2}{*}{$\begin{array}{l}\text { Edara et al., } \\
2021 \mathrm{a}\end{array}$} & mRNA-1273 & 15 participants (35-51 d ater the 2nd dose) & FRNT using WA1/2020 and B.1.617.2 & $\begin{array}{l}\downarrow 3 \times \text { in neutralizing } \\
\text { B.1.617.2 }\end{array}$ \\
\hline & $\begin{array}{l}\text { Convalescent } \\
\text { plasma }\end{array}$ & $\begin{array}{l}24 \text { convalescent plasma (31-91 d after the } \\
\text { onset of symptons) }\end{array}$ & & $\begin{array}{l}\downarrow 2.4 \times \text { in neutralizing } \\
\text { B.1.617.2 }\end{array}$ \\
\hline \multirow[t]{3}{*}{$\begin{array}{l}\text { Edara et al., } \\
2021 b\end{array}$} & mRNA-1273 & 19 participants (14 d after the 2nd dose) & $\begin{array}{l}\text { IgG Ab binding by electrochemiluminescence- based } \\
\text { multiplex immune assay }\end{array}$ & $\begin{array}{l}\downarrow 3.7 \text { and } 3.8 \times \text { Ab binding } \\
\text { and virus neutralization } \\
\text { (B.1.351) }\end{array}$ \\
\hline & $\begin{array}{l}\text { Acutely } \\
\text { infected } \\
\text { people }\end{array}$ & $\begin{array}{l}19 \text { acutely infected participants (5-19 d after } \\
\text { the onset of symptons) }\end{array}$ & Live virus neutralization using B.1 and B.1.351 & $\begin{array}{l}\downarrow 4.4 \text { and } 3.3 \times \text { Ab binding } \\
\text { and virus neutralization } \\
\text { (B.1.351) }\end{array}$ \\
\hline & $\begin{array}{l}\text { Convalescent } \\
\text { plasma }\end{array}$ & $\begin{array}{l}30 \text { participants ( } 1-3 \text { and } 3-8 \text { mo after the } \\
\text { onset of symptons) }\end{array}$ & & $\begin{array}{l}\downarrow 4.4 \text { and } 3.3 \times \text { Ab binding } \\
\text { and } 4.8 \text { and } 2.1 \times \text { virus } \\
\text { neutralization (B.1.351) }\end{array}$ \\
\hline $\begin{array}{l}\text { Emary } \\
\text { et al., } 2021\end{array}$ & AZD1222 & $\begin{array}{l}\text { 8,534 participants (1:1 AZD1222 vaccine vs } \\
\text { meningococcal vaccine) }\end{array}$ & Clinical trial, phase $2 / 3$, in the U.K. & $\begin{array}{l}70.4 \% \text { efficacy against } \\
\text { B.1.1.7 variant vs } 81.5 \% \\
\text { efficacy against non-B.1.1.7 } \\
\text { lineages }\end{array}$ \\
\hline
\end{tabular}


TABLE 2 | Continued

\begin{tabular}{|c|c|c|c|c|}
\hline Study & $\begin{array}{l}\text { Vaccine or } \\
\text { plasma }\end{array}$ & Sample size & Methodology & Main findings \\
\hline \multirow[t]{2}{*}{$\begin{array}{l}\text { Geers } \\
\text { et al., } 2021\end{array}$} & BNT 162b2 & $\begin{array}{l}25 \text { health care workers ( } 2-3 \text { wks after the } \\
1 \text { st dose and } 3-4 \text { wks after the } 2 \text { nd dose) }\end{array}$ & $\begin{array}{l}\text { PRNT assay against D614G strain and VOCs (B.1.1.7 and } \\
\text { B.1.351) }\end{array}$ & $\begin{array}{l}\uparrow 2.5 \text { and } 2.2 X \text { after the } \\
\text { 1st and } 2 \text { nd dose in } \\
\text { neutralizing B.1.1.7 } \\
\downarrow 2.7 \text { and } 3.3 X \text { after the } \\
\text { 1st and 2nd dose in } \\
\text { neutralizing B.1.351 }\end{array}$ \\
\hline & $\begin{array}{l}\text { Convalescent } \\
\text { plasma }\end{array}$ & $\begin{array}{l}13 \text { health care workers ( } 3 \text { wks after the } \\
\text { onset of symptons) }\end{array}$ & & $\begin{array}{l}\uparrow 2.8 X \text { in neutralizing } \\
\text { B.1.1.7 and } \downarrow 3 X \text { in } \\
\text { neutralizing } B .1 .351\end{array}$ \\
\hline $\begin{array}{l}\text { Gushchin } \\
\text { et al., } 2021\end{array}$ & Sputnik V & 27 vaccinee serum (30 d after the 2 nd dose) & $\begin{array}{l}\text { Virus neutralization against different strains (D614G, B.1.1.7, } \\
\text { B.1.351, P.1, and B.1.617.2) }\end{array}$ & $\begin{array}{l}\downarrow 0,3.1,2.8 \text {, and } 2.5 X \text { in } \\
\text { neutralizing B.1.1.7, } \\
\text { B.1.351, P.1, and } \\
\text { B.1.617.2 }\end{array}$ \\
\hline \multirow[t]{2}{*}{$\begin{array}{l}\text { Hoffmann } \\
\text { et al., } 2021\end{array}$} & BNT 162b2 & 15 donors, $13-15 \mathrm{~d}$ after the 2 nd dose & $\begin{array}{l}\text { Entry of pseudotyped particles with different S protein strains } \\
\text { (W.T., B.1.1.7, B.1.31, or P1) into target Vero cells }\end{array}$ & $\begin{array}{l}\text { B.1.1.7: slight effect } \\
\text { B.1.351 and } \mathrm{P} 1: \downarrow \mathrm{nAb} \\
\text { activity }\end{array}$ \\
\hline & $\begin{array}{l}\text { Convalescent } \\
\text { plasma }\end{array}$ & $\begin{array}{l}\text { Individuals previously infected with WT } \\
\text { SARSCoV-2 }\end{array}$ & & $\begin{array}{l}\text { B.1.1.7: slight effect } \\
\text { B.1.351 and } \mathrm{P} 1: \downarrow \mathrm{nAb} \\
\text { activity }\end{array}$ \\
\hline \multirow[t]{2}{*}{$\begin{array}{l}\text { Kuzmina } \\
\text { et al., } 2021\end{array}$} & BNT 162b2 & $\begin{array}{l}10 \text { vaccinee serum ( } 21 \mathrm{~d} \text { after the } 1 \text { st dose } \\
\text { or } 9-11 \mathrm{~d} \text { after the } 2^{\text {nd }} \text { dose) }\end{array}$ & $\begin{array}{l}\text { Pseudovirus neutralization against wildtype strain or VOCs } \\
\text { (B.1.1.7 and B.1.351) }\end{array}$ & $\begin{array}{l}\text { No effect in neutralizing } \\
\text { B.1.1.7 } \\
\downarrow 6.8 \times \text { in neutralizing } \\
\text { B.1.351 }\end{array}$ \\
\hline & $\begin{array}{l}\text { Convalescent } \\
\text { plasma }\end{array}$ & 10 COVID19 recovered patients & & $\begin{array}{l}\downarrow 1.5 X \text { in neutralizing } \\
\text { B.1.1.7 } \\
\downarrow 6.8 X \text { in neutralizing } \\
\text { B.1.351 }\end{array}$ \\
\hline \multirow[t]{3}{*}{$\begin{array}{l}\text { Liu C. } \\
\text { et al., } 2021\end{array}$} & BNT 162b2 & $\begin{array}{l}25 \text { vaccinee serum }\left(7-17 d \text { after the } 2^{\text {nd }}\right. \\
\text { dose) }\end{array}$ & $\begin{array}{l}\text { Live virus neutralization assay by FRNT using Victoria strain } \\
\text { and VOCs (B.1.1.7, B.1.351, P.1, and B.1.617.2 variants) }\end{array}$ & $\begin{array}{l}\downarrow 3.2,7.5,2.6 \text {, and } 2.5 \mathrm{X} \text { in } \\
\text { neutralizing B.1.1.7, } \\
\text { B.1.351, P.1, and } \\
\text { B.1.617.2 }\end{array}$ \\
\hline & AZD1222 & $\begin{array}{l}25 \text { vaccinee serum (14-28 d after the } 2^{\text {nd }} \\
\text { dose) }\end{array}$ & & $\begin{array}{l}\downarrow 2.3,9,2.8 \text {, and } 4.2 \mathrm{X} \text { in } \\
\text { neutralizing B.1.1.7, } \\
\text { B.1.351, P.1, and } \\
\text { B.1.617.2 }\end{array}$ \\
\hline & $\begin{array}{l}\text { Convalescent } \\
\text { plasma }\end{array}$ & 34 volunteers (4-9 wks after the infection) & & $\begin{array}{l}\downarrow 2.9,13.3,3.1 \text {, and } 2.6 \times \\
\text { in neutralizing B.1.1.7, } \\
\text { B.1.351, P.1, and } \\
\text { B.1.617.2 }\end{array}$ \\
\hline $\begin{array}{l}\text { Lustig } \\
\text { et al., } 2021\end{array}$ & BNT 162b2 & $\begin{array}{l}\text { 15-19 vaccinee serum ( } 30 \mathrm{~d} \text { after the } 2^{\text {nd }} \\
\text { dose) }\end{array}$ & $\begin{array}{l}\text { Neutralizing original (B.1) and VOCs strains (B.1.1.7, B.1.351, } \\
\text { P.1, and B.1.617.2) and virus entry in VERO-E6 cells }\end{array}$ & $\begin{array}{l}\downarrow 1.7,10.4,2.3 \text {, and } 2.1- \\
2.6 \mathrm{X} \text { in neutralizing } \\
\text { B.1.1.7, B.1.351, P.1 and } \\
\text { B.1.617.2 }\end{array}$ \\
\hline \multirow[t]{2}{*}{$\begin{array}{l}\text { Madhi } \\
\text { et al., } 2021\end{array}$} & AZD1222 & $\begin{array}{l}\text { 2,026 participants (1:1 AZD1222 vaccine or } \\
\text { placebo) }\end{array}$ & $\begin{array}{l}\text { Clinical, multicenter, double-blind, randomized trial, in the } \\
\text { South Africa }\end{array}$ & $\begin{array}{l}21.9 \% \text { efficacy against mild } \\
\text { to moderate COVID-19 } \\
10.4 \% \text { efficacy against } \\
\text { B. } 1.351\end{array}$ \\
\hline & ChAdOx1-S & 10 vaccinee serum (after the $2^{\text {nd }}$ dose) & $\begin{array}{l}\text { Pseudovirus neutralization against D614G strain and B.1.1.7 } \\
\text { and B.1.617.2 variants }\end{array}$ & $\begin{array}{l}\downarrow 3.4 \text { and } 9.0 \times \text { in } \\
\text { neutralizing } B .1 .1 .7 \text { and } \\
\text { B.1.617.2 }\end{array}$ \\
\hline \multirow[t]{2}{*}{$\begin{array}{l}\text { Mlcochova } \\
\text { et al., } 2021\end{array}$} & BNT 162b2 & 10 vaccinee serum (after the $2^{\text {nd }}$ dose) & $\begin{array}{l}\text { Pseudovirus neutralization against D614G strain and B.1.1.7 } \\
\text { and B.1.617.2 variants }\end{array}$ & $\begin{array}{l}\downarrow 5.8 \text { and } 8.4 X \text { in } \\
\text { neutralizing } B .1 .1 .7 \text { and } \\
\text { B.1.617.2 }\end{array}$ \\
\hline & $\begin{array}{l}\text { Convalescent } \\
\text { plasma }\end{array}$ & 12 volunteers & $\begin{array}{l}\text { Pseudovirus neutralization against D614G strain and B.1.1.7, } \\
\text { B.1.351, and B.1.617.2 variants }\end{array}$ & $\begin{array}{l}\downarrow 2.3,8.2 \text {, and } 5.7 X \text { in } \\
\text { neutralizing B.1.1.7, } \\
\text { B.1.351, and B.1.617.2 }\end{array}$ \\
\hline $\begin{array}{l}\text { Muik et al., } \\
2021\end{array}$ & BNT 162b2 & $\begin{array}{l}40 \text { vaccinee serum ( } 7 \text { or } 21 \mathrm{~d} \text { after the } 2^{\text {nd }} \\
\text { dose) }\end{array}$ & $\begin{array}{l}\text { Neutralizing VSV pseudovirus (Wuhan strain and B.1.1.7 S } \\
\text { mutants) entry in HEK-hACE2 cells }\end{array}$ & $\begin{array}{l}\downarrow \text { (light reduction) in } \\
\text { neutralizaing B.1.1.7 }\end{array}$ \\
\hline $\begin{array}{l}\text { Planas } \\
\text { et al., } 2021\end{array}$ & BNT 162b2 & $\begin{array}{l}16 \text { vaccinee serum ( } 5 \text { wks after the } 2^{\text {nd }} \\
\text { dose) }\end{array}$ & $\begin{array}{l}\text { S-Fuse neutralization assay against D614G strain and VOCs } \\
\text { strains (B.1.1.7, B.1.351, and B.1.617.2) }\end{array}$ & $\begin{array}{l}\downarrow 0,16 \text {, and } 3 X \text { in } \\
\text { neutralizing } B \cdot 1.1 .7 \\
\text { B.1.351, and B.1.617.2 }\end{array}$ \\
\hline
\end{tabular}


TABLE 2 | Continued

\begin{tabular}{|c|c|c|c|c|}
\hline Study & $\begin{array}{l}\text { Vaccine or } \\
\text { plasma }\end{array}$ & Sample size & Methodology & Main findings \\
\hline \multirow{5}{*}{$\begin{array}{l}\text { Shen et al., } \\
2021\end{array}$} & AZD1222 & $\begin{array}{l}20 \text { vaccinee serum ( } 4 \text { wks after the } 2^{\text {nd }} \\
\text { dose) }\end{array}$ & & $\begin{array}{l}\downarrow 0,9 \text {, and } 5 \mathrm{X} \text { in } \\
\text { neutralizing } \mathrm{B} \cdot 1.1 .7 \\
\text { B.1.351, and B.1.617.2 }\end{array}$ \\
\hline & $\begin{array}{l}\text { Convalescent } \\
\text { plasma }\end{array}$ & $\begin{array}{l}26 \text { convalesdent plasma (12 mo after the } \\
\text { onset of symptons) }\end{array}$ & & $\begin{array}{l}\downarrow 0,4 \text {, and } 4 \mathrm{X} \text { in } \\
\text { neutralizing } \mathrm{B} \cdot 1.1 .7 \\
\text { B.1.351, and B.1.617.2 }\end{array}$ \\
\hline & mRNA-1273 & 28 vaccinee serum (28 d after the 2 nd dose) & & $\downarrow 2 X$ in neutralizing B.1.1.7 \\
\hline & $\begin{array}{l}\text { NVX- } \\
\text { CoV2373 }\end{array}$ & $\begin{array}{l}28 \text { vaccinee serum ( } 2 \text { wks after the } 2 \text { nd } \\
\text { dose) }\end{array}$ & $\begin{array}{l}\text { Pseudovirus neutralization assay using D614G strain and } \\
\text { B.1.1.7 variant }\end{array}$ & $\downarrow 2 X$ in neutralizing B.1.1.7 \\
\hline & $\begin{array}{l}\text { Convalescent } \\
\text { plasma }\end{array}$ & $\begin{array}{l}15 \text { convalesdent plasma ( } 4 \text { - } 9 \text { mo after } \\
\text { infection) }\end{array}$ & & $\begin{array}{l}\downarrow 1.5 \times \text { in neutralizing } \\
\text { B.1.1.7 }\end{array}$ \\
\hline \multirow{4}{*}{$\begin{array}{l}\text { Shinde } \\
\text { et al., } 2021 \\
\text { Supasa } \\
\text { et al., } 2021\end{array}$} & $\begin{array}{l}\text { NVX- } \\
\text { CoV2373 }\end{array}$ & $\begin{array}{l}\text { 4,387 participants (2,199 vaccinated and } \\
\text { 2,188 with placebo) }\end{array}$ & Clinical trial, phase $2 a / b$, in the South Africa & $\begin{array}{l}\downarrow \text { Efficacy against B.1.351 } \\
(49.4 \%)\end{array}$ \\
\hline & BNT 162b2 & $\begin{array}{l}25 \text { vaccinee serum }\left(7-17 \mathrm{~d} \text { after the } 2^{\text {nd }}\right. \\
\text { dose) }\end{array}$ & & $\begin{array}{l}\downarrow 3.3 \times \text { in neutralizing } \\
\text { B.1.1.7 }\end{array}$ \\
\hline & AZD1222 & $\begin{array}{l}10-15 \text { vaccinee serum (14- } 28 d \text { after the } \\
2^{\text {nd }} \text { dose) }\end{array}$ & FRNT using Victoria and B.1.1.7 strains & $\begin{array}{l}\downarrow 2.1-2.5 \times \text { in neutralizing } \\
\text { B.1.1.7 }\end{array}$ \\
\hline & $\begin{array}{l}\text { Convalescent } \\
\text { plasma }\end{array}$ & $\begin{array}{l}34 \text { convalesdent plasma ( } 4 \text { - } 9 \text { mo after } \\
\text { infection) }\end{array}$ & & $\begin{array}{l}\downarrow 2.9 \times \text { in neutralizing } \\
\text { B.1.1.7 }\end{array}$ \\
\hline $\begin{array}{l}\text { Wall et al., } \\
2021\end{array}$ & BNT 162b2 & $\begin{array}{l}250 \text { Individuals who worked at UCLH in UK } \\
\text { and had received the vaccine ( } 3 \text { weeks, } 6 \\
\text { and } 12 \text { weeks pos-vaccination) }\end{array}$ & $\begin{array}{l}\text { RT-qPCR to exclude active infection; Blood was collected for } \\
\text { serological assays including anti-spike lgG, IgM and live-virus } \\
\text { neutralization; High-throughput live virus microneutralization } \\
\text { assays }\end{array}$ & $\begin{array}{l}\text { Reduction neutralizing } \\
\text { antibodies activity against } \\
\text { B.1.617.2 and B.1.351. }\end{array}$ \\
\hline \multirow[t]{3}{*}{$\begin{array}{l}\text { Wang } \\
\text { et al., } 2021\end{array}$} & CoronaVac & $\begin{array}{l}25 \text { vaccinee serum ( } 2-3 \text { wks after the } 2^{\text {nd }} \\
\text { dose) }\end{array}$ & & $\begin{array}{l}\downarrow 2 \text { and } 3.3 X \text { in neutralizing } \\
\text { B.1.1.7 and B.1.351 }\end{array}$ \\
\hline & BBIBP-CorV & $\begin{array}{l}25 \text { vaccinee serum ( } 2-3 \text { wks after the } 2^{\text {nd }} \\
\text { dose) }\end{array}$ & $\begin{array}{l}\text { Pseudovirus neutralization against different strains (Wuhan-1 } \\
\text { wild-type, D614G, B.1.1.7, and B.1.351) }\end{array}$ & $\begin{array}{l}\downarrow 0 \text { and } 2.5 X \text { in neutralizing } \\
\text { B.1.1.7 and B.1.351 }\end{array}$ \\
\hline & $\begin{array}{l}\text { Convalescent } \\
\text { plasma }\end{array}$ & $\begin{array}{l}34 \text { convalescent plasma ( } 5 \text { mo. After } \\
\text { infection) }\end{array}$ & & $\begin{array}{l}\downarrow 1.1 \text { and } 2 X \text { in neutralizing } \\
\text { B.1.1.7 and B.1.351 }\end{array}$ \\
\hline $\begin{array}{l}\text { Wibmer } \\
\text { et al., } 2021\end{array}$ & $\begin{array}{l}\text { Convalescent } \\
\text { plasma }\end{array}$ & $\begin{array}{l}44 \text { participants (mild-tomoderate and severe } \\
\text { COVID-19) }\end{array}$ & $\begin{array}{l}\text { Pseudovirus neutralization assay using D614G strain and } \\
\text { B.1.351 variant }\end{array}$ & $\begin{array}{l}48 \% \text { of the samples: loss of } \\
\text { the neutralizing activity } \\
\text { against B. } 1.351\end{array}$ \\
\hline $\begin{array}{l}\text { Wu et al., } \\
2021\end{array}$ & mRNA-1273 & $\begin{array}{l}28 \text { vaccinee serum (one week after the } 2^{\text {nd }} \\
\text { dose) }\end{array}$ & $\begin{array}{l}\text { Pseudovirus neutralization assay using D614G strain and } \\
\text { VOCs (B.1.1.7, B.1.351, and P.1 strains) }\end{array}$ & $\begin{array}{l}\downarrow 1.2,6.4,3.5 \mathrm{X} \text { in } \\
\text { neutralizing B.1.1.7, } \\
\text { B.1.351, and P.1 }\end{array}$ \\
\hline \multirow[t]{3}{*}{$\begin{array}{l}\text { Zhou et al., } \\
2021\end{array}$} & BNT 162b2 & $\begin{array}{l}25 \text { vaccinee serum ( } 4-17 d \text { after the } 2^{\text {nd }} \\
\text { dose) }\end{array}$ & & $\begin{array}{l}\downarrow 7.6 \times \text { in neutralizing } \\
\text { B.1.1.7 }\end{array}$ \\
\hline & AZD1222 & 25 vaccinee serum ( $28 \mathrm{~d}$ after the $2^{\text {nd }}$ dose) & FRNT using Victoria and B.1.351 strains & $\downarrow 9 X$ in neutralizing B.1.1.7 \\
\hline & $\begin{array}{l}\text { Convalescent } \\
\text { plasma }\end{array}$ & $\begin{array}{l}34 \text { convalesdent plasma (4- } 9 \text { mo after } \\
\text { infection) }\end{array}$ & & $\begin{array}{l}\downarrow 13.3 \times \text { in neutralizing } \\
\text { B. } 1.351\end{array}$ \\
\hline
\end{tabular}

FRNT, focus reduction neutralization test; PRNT, plaque reduction neutralization test; VSV, vesicular stomatitis virus.

of September 2, 2021. Except for South Africa, Reunion, Angola, Philippines, Hong Kong, Bangladesh, and Qatar, the B.1.351 variant did not increase by more than $10 \%$ in most countries analyzed (Figure 4). A similar result was observed with the P.1 variant, which emerged in Brazil in December 2020. This variant disseminated at low rates $(<10 \%)$ in 78 countries (Sep 2, 2021) but had a high prevalence in Brazil, Chile, and French Guiana (Figure 4).

The emergent B.1.617.2 variant appeared in India in October 2020. It has been dispersed throughout 147 countries (Sep 2, 2021) and has a high predominance rate in most analyzed countries. For example, more than $80 \%$ of COVID-19 cases were B.1.617.2-induced in 52 of the 67 countries analyzed; 4 had between 50.1 to $80 \%$, and 11 had less than $50 \%$. Notably, there is an increasing trend in the countries with fewer B.1.617.2-related cases. Currently, this variant is the most prevalent VOC, displaying rapid transmission and spread and indicative of selective advantages against other VOCs such as B.1.1.7, B.1.351, and P.1. It will likely become predominant worldwide. Fortunately, B.1.617.2's high predominance has not increased the number of cases, hospitalizations or deaths, and the current vaccines effectively protect against all known VOCs.

\section{PERSPECTIVES AND CONCLUDING REMARKS}

Viral evolution is a constant process and can eventually improve "viral fitness" and selective adaptation. Emerging SARS-CoV-2 variants have posed challenges for authorities and scientists around the world. Although vaccines currently provide high protection against all VOCs, constant surveillance of vaccine efficacy is essential for combating the main SARS-CoV-2 strains and potentially new emerging variants. 


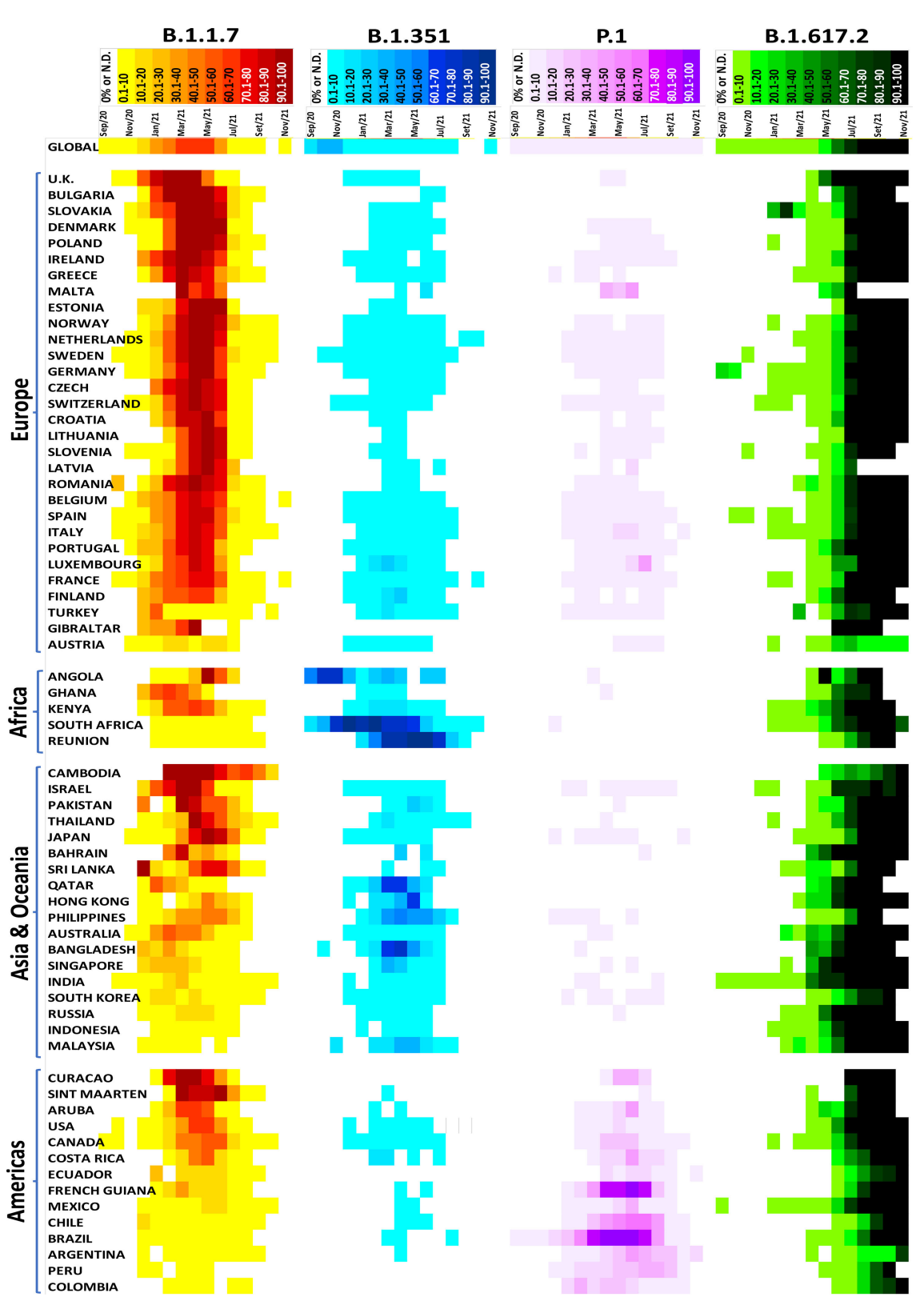

FIGURE 4 | Distribution of the SARS-CoV-2 variants of concern in several countries. Data were analyzed from GISAID from September 2020 to November 2021 (https://www.gisaid.org/hcov19-variants/).

The main concern is that a VOC can partially or completely evade the immune response, increasing reinfection of the individuals already infected by previous strains, limited protection induced by vaccination, and impaired efficacy of therapies based on monoclonal nAbs or convalescent plasma and consequently heightening the risk for future COVID-19 pandemic waves. Indeed, it has been proposed that the COVID19 pandemic will persist for a long time with more mutations and emerging VOCs. Thus, actions must be undertaken to combat the COVID-19 pandemic and emerging VOCs. Below, we have highlighted seven key points that could prevent the rise of new SARS-CoV-2 variants:

1. Rapid and massive worldwide vaccinations against COVID-19 to reduce new infections. This point is based on the fact that slowing viral dissemination will reduce the probability of viral mutations and the emergence of new variants. However, vaccination campaigns are limited in some parts of the world. Thus, in these areas, strict public health measures and efficient strategies to stop or decrease virus transmission 
(e.g., face masks, frequent hand sanitation, social distancing, and other precautions) are the best defense against this virus.

2. Constant and active global surveillance and identification of circulating and emerging VOCs and subsequent characterization. Efficient monitoring systems will allow rapid detection, isolation, and response against new VOCs, avoiding uncontrolled dissemination and future pandemic waves.

3. Determining vaccine and neutralizing antibody efficacy against VOCs. If the vaccines do not present broad protection against the virus variants, periodic vaccine updates or redevelopment will be required, as occurs with the $\mathrm{H} 1 \mathrm{~N} 1$ vaccine. Other possibilities include developing new vaccines that induce nAbs against different variants by targeting highly conserved antigenic epitopes of the $S$ protein and/or combining different vaccines or monoclonal Abs to target specific variants.

4. Establish plasma repositories from individuals previously infected with different variants and immunized with different COVID-19 vaccines. This point aims to rapidly determine the nAb activity against new VOCs and the potential for immune evasion. Determining the $\mathrm{nAb}$ titers and the period of protection induced by previous infection or vaccination is essential to determine further actions.

5. Surveillance of reinfections, especially in already immunized or previously infected individuals. This action could be a good strategy for assessing the potential immune evasion of new VOCs.

6. Studies with combinations of available vaccines to improve efficacy and protection. Monitoring the $\mathrm{nAb}$ levels for the $\mathrm{S}$ protein in fully vaccinated people can provide insights into protection since high levels of these antibodies seem to confer defense against emerging VOCs.

7. Application of an additional booster vaccine dose to increasel prolong the neutralizing antibody titers over time. This proposal is based on three points: a) high-risk groups, including immunocompromised and the elderly, present a reduced immune response following immunization; b) antibody titers decrease months after the complete vaccination schedule (14-21 days after the single dose Janssen vaccine or two doses of the other vaccines); and

\section{REFERENCES}

Abdel-Moneim, A. S., Abdelwhab, E. M., and Memish, Z. A. (2021). Insights Into SARS-CoV-2 Evolution, Potential Antivirals, and Vaccines. Virology 558, 1-12. doi: 10.1016/j.virol.2021.02.007

Abu-Raddad, L. J., Chemaitelly, H., and Butt, A. A., National Study Group for COVID-19 Vaccination. (2021). Effectiveness of the BNT162b2 Covid-19 Vaccine against the B.1.1.7 and B.1.351 Variants. N. Engl. J. Med. 385 (2), 187-189. doi: 10.1056/NEJMc2104974

Adam, D. (2021). What Scientists Know About New, Fast-Spreading Coronavirus Variants. Nature 594, 19-20. doi: 10.1038/d41586-021-01390-4

Alter, G., Yu, J., Liu, J., Chandrashekar, A., Borducchi, E. N., Tostanoski, L. H., et al. (2021). Immunogenicity of Ad26.COV2.S Vaccine Against SARS-CoV-2 Variants in Humans. Nature 596 (7871), 268-272. doi: 10.1038/s41586-02103681-2

Altmann, D. M., Boyton, R. J., and Beale, R. (2021). Immunity to SARS-CoV-2 Variants of Concern. Science 371 (6534), 1103-1104. doi: 10.1126/science.abg7404 c) the emergence of VOCs may require high $\mathrm{nAb}$ titers for protection. Vaccine booster administration is already occurring in some countries, including the USA, Israel, and Brazil, especially in high-risk groups/individuals.

\section{AUTHOR CONTRIBUTIONS}

All authors attended the criteria to justify the authorship. Specifically, SH, DC, RC, and ED conceived the study. SH, TS, RG, LM, and TP-C elaborated the figures and tables, made the literature review and wrote the manuscript. DC, RC, and ED assisted the writing and revision of the manuscript. All authors have read, revised, and approved the final version of the submitted manuscript.

\section{FUNDING}

The authors of this study are supported by grants from the São Paulo Research Foundation (FAPESP, Sao Paulo, SP, Brazil; 2018/09868-7 and 2021/00200-6), the Coordination for the Improvement of Higher Education Personnel (CAPES, Brasilia, Brazil), the National Council for Scientific and Technological Development (CNPq, Brasilia, Brazil), the John Simon Guggenheim Memorial Foundation (JSGMF, New York, NY, USA), and the Pro-Rectory of Post-Graduate and Research of the Cruzeiro do Sul University (PRPGP/Cruzeiro do Sul, São Paulo, SP, Brazil).

\section{ACKNOWLEDGMENTS}

The authors would like to thank Dr. Renato Padovese from the Cruzeiro do Sul University, São Paulo, SP, Brazil, for the continuous academic and financial support. The Authors also want to acknowledge the Global Initiative on Sharing All Influenza Data (GISAID) and the scientists who contributed and submitted genomic data to this public database.

Baden, L. R., El Sahly, H. M., Essink, B., Kotloff, K., Frey, S., Novak, R., et al (2021). Efficacy and Safety of the mRNA-1273 SARS-CoV-2 Vaccine. N. Engl. J. Med. 384, 403-416. doi: 10.1056/NEJMoa2035389

Callaway, E. (2021). Heavily Mutated Omicron Variant Puts Scientists on Alert. Nature 600 (7887), 21. doi: 10.1038/d41586-021-03552-w

Callaway, E., and Ledford, H. (2021). How to Redesign COVID Vaccines So They Protect Against Variants. Nature 590 (7844), 15-16. doi: 10.1038/d41586-02100241-6

Callaway, E., and Mallapaty, S. (2021). Novavax Offers First Evidence That COVID Vaccines Protect People Against Variants. Nature 590 (7844), 17. doi: 10.1038/d41586-021-00268-9

Chen, J., and Lu, H. (2021). New Challenges to Fighting COVID-19: Virus Variants, Potential Vaccines, and Development of Antivirals. Biosci. Trends. 15 (2), 126-128. doi: 10.5582/bst.2021.01092

Chen, Y., Shen, H., Huang, R., Tong, X., and Wu, C. (2021). Serum Neutralising Activity Against SARS-CoV-2 Variants Elicited by CoronaVac. Lancet Infect. Dis. 21 (8), 1071-1072. doi: 10.1016/S1473-3099(21)00287-5 
Chen, R. E., Zhang, X., Case, J. B., Winkler, E. S., Liu, Y., VanBlargan, L. A., et al. (2021). Resistance of SARS-CoV-2 Variants to Neutralization by Monoclonal and Serum-Derived Polyclonal Antibodies. Nat. Med. 27 (4), 717-726. doi: 10.1038/s41591-021-01294-w

Cherian, S., Potdar, V., Jadhav, S., Yadav, P., Gupta, N., Das, M., et al. (2021). SARS-CoV-2 Spike Mutations, L452R, T478K, E484Q and P681R, in the Second Wave of COVID-19 in Maharashtra, India. Microorganisms 9 (7), 1542. doi: 10.3390/microorganisms 9071542

Choi, B., Choudhary, M. C., Regan, J., Sparks, J. A., Padera, R. F., Qiu, X., et al. (2020). Persistence and Evolution of SARS-CoV-2 in an Immunocompromised Host. N. Engl. J. Med. 383, 2291-2293. doi: 10.1056/NEJMc2031364

Choi, A., Koch, M., Wu, K., Dixon, G., Oestreicher, J., Legault, H., et al. (2021). Serum Neutralizing Activity of mRNA-1273 Against SARS-CoV-2 Variants. J. Virol. 95 (23), e0131321. doi: 10.1128/JVI.01313-21

Collier, D. A., De Marco, A., Ferreira, I. A. T. M., Meng, B., Datir, R. P., Walls, A. C., et al. (2021). Sensitivity of SARS-CoV-2 B.1.1.7 to mRNA Vaccine-Elicited Antibodies. Nature 593 (7857), 136-141. doi: 10.1038/s41586-021-03412-7

Conti, P., Caraffa, A., Gallenga, C. E., Kritas, S. K., Frydas, I., Younes, A., et al. (2021). The British Variant of the New Coronavirus-19 (Sars-Cov-2) Should Not Create a Vaccine Problem. J. Biol. Regul. Homeost. Agents. 35 (1), 1-4. doi: 10.23812/21-3-E

Davies, N. G., Jarvis, C. I.CMMID COVID-19 Working Group, , Edmunds, W. J., Jewell, N. P., Diaz-Ordaz, K., et al. (2021). Increased Mortality in CommunityTested Cases of SARS-CoV-2 Lineage B.1.1.7. Nature 593 (7858), 2707-274. doi: 10.1038/s41586-021-03426-1

Dearlove, B., Lewitus, E., Bai, H., Li, Y., Reeves, D. B., Joyce, M. G., et al. (2020). A SARS-CoV-2 Vaccine Candidate Would Likely Match All Currently Circulating Variants. Proc. Natl. Acad. Sci. U. S. A. 117 (38), 23652-23662. doi: $10.1073 /$ pnas.2008281117

Dejnirattisai, W., Zhou, D., Supasa, P., Liu, C., Mentzer, A. J., Ginn, H. M., et al. (2021). Antibody Evasion by the P.1 Strain of SARS-CoV-2. Cell 184 (11), 2939-2954.e9. doi: 10.1016/j.cell.2021.03.055

Edara, V. V., Norwood, C., Floyd, K., Lai, L., Davis-Gardner, M. E., Hudson, W. H., et al. (2021b). Infection- and Vaccine-Induced Antibody Binding and Neutralization of the B.1.351 SARS-CoV-2 Variant. Cell Host Microbe 29 (4), 516-521. doi: 10.1016/j.chom.2021.03.009

Edara, V. V., Pinsky, B. A., Suthar, M. S., Lai, L., Davis-Gardner, M. E., Floyd, K., et al. (2021a). Infection and Vaccine-Induced Neutralizing-Antibody Responses to the SARS-CoV-2 B.1.617 Variants. N. Engl. J. Med. 385 (7), 664-666. doi: 10.1056/NEJMc2107799

Emary, K. R. W., Golubchik, T., Aley, P. K., Ariani, C. V., Angus, B., Bibi, S., et al. (2021). Efficacy of ChAdOx1 Ncov-19 (AZD1222) Vaccine Against SARSCoV-2 Variant of Concern 202012/01 (B.1.1.7): An Exploratory Analysis of a Randomised Controlled Trial. Lancet 397 (10282), 1351-1362. doi: 10.1016/ S0140-6736(21)00628-0

Finkel, Y., Mizrahi, O., Nachshon, A., Weingarten-Gabbay, S., Morgenstern, D., Yahalom-Ronen, Y., et al. (2021). The Coding Capacity of SARS-CoV-2. Nature 589 (7840), 125-130. doi: 10.1038/s41586-020-2739-1

Flower, T. G., Buffalo, C. Z., Hooy, R. M., Allaire, M., Ren, X., and Hurley, J. H. (2021). Structure of SARS-Cov-2 ORF8, a Rapidly Evolving Immune Evasion Protein. Proc. Natl. Acad. Sci. U. S. A. 118, 1-6. doi: 10.1073/pnas.2021785118

Focosi, D., and Maggi, F. (2021). Neutralising Antibody Escape of SARS-CoV-2 Spike Protein: Risk Assessment for Antibody-Based Covid-19 Therapeutics and Vaccines. Rev. Med. Virol. 31 (6), e2231. doi: 10.1002/rmv.2231

Fontanet, A., Autran, B., Lina, B., Kieny, M. P., Karim, S. S. A., and Sridhar, D. (2021). SARS-CoV-2 Variants and Ending the COVID-19 Pandemic. Lancet 397 (10278), 952-954. doi: 10.1016/S0140-6736(21)00370-6

Francisco, R. D. S. Jr, Benites, L. F., Lamarca, A. P., de Almeida, L. G. P., Hansen, A. W., Gularte, J. S., et al. (2021). Pervasive Transmission of E484K and Emergence of VUI-NP13L With Evidence of SARS-CoV-2 Co-Infection Events by Two Different Lineages in Rio Grande do Sul, Brazil. Virus Res. 296, 198345. doi: 10.1016/j.virusres.2021.198345

Garcia-Beltran, W. F., Lam, E. C., Astudillo, M. G., Yang, D., Miller, T. E., Feldman, J., et al. (2021b). COVID-19-Neutralizing Antibodies Predict Disease Severity and Survival. Cell 184, 476-488.e11. doi: 10.1016/j.cell.2020. 12.015

Garcia-Beltran, W. F., Lam, E. C., St Denis, K., Nitido, A. D., Garcia, Z. H., Hauser, B. M., et al. (2021a). Multiple SARS-CoV-2 Variants Escape Neutralization by
Vaccine-Induced Humoral Immunity. Cell 184 (9), 2372-2383.e9. doi: 10.1016/j.cell.2021.03.013

Geers, D., Shamier, M. C., Bogers, S., den Hartog, G., Gommers, L., Nieuwkoop, N. N., et al. (2021). SARS-CoV-2 Variants of Concern Partially Escape Humoral But Not T-Cell Responses in COVID-19 Convalescent Donors and Vaccinees. Sci. Immunol. 6 (59), eabj1750. doi: 10.1126/sciimmunol.abj1750

GISAID (Global Initiative on Sharing All Influenza Data). (2021). Tracking of Variants. Available at: https://www.gisaid.org/hcov19-variants/.

Gobeil, S. M., Janowska, K., McDowell, S., Mansouri, K., Parks, R., Manne, K., et al. (2021). D614G Mutation Alters SARS-CoV-2 Spike Conformation and Enhances Protease Cleavage at the S1/S2 Junction. Cell Rep. 34, 108630. doi: 10.1016/j.celrep.2020.108630

Graham, M. S., Sudre, C. H., May, A., Antonelli, M., Murray, B., Varsavsky, T., et al. (2021). Changes in Symptomatology, Reinfection, and Transmissibility Associated With the SARS-CoV-2 Variant B.1.1.7: An Ecological Study. Lancet Public Health 6 (5), e335-e345. doi: 10.1016/S2468-2667(21)00055-4

Groves, D. C., Rowland-Jones, S. L., and Angyal, A. (2021). The D614G Mutations in the SARS-CoV-2 Spike Protein: Implications for Viral Infectivity, Disease Severity and Vaccine Design. Biochem. Biophys. Res. Commun. 538, 104-107. doi: 10.1016/j.bbrc.2020.10.109

Gu, H., Chen, Q., Yang, G., He, L., Fan, H., Deng, Y. Q., et al. (2020). Adaptation of SARS-CoV-2 in BALB/c Mice for Testing Vaccine Efficacy. Science 369, 1603 1607. doi: 10.1126/science.abc4730

Gushchin, V. A., Dolzhikova, I. V., Shchetinin, A. M., Odintsova, A. S., Siniavin, A. E., Nikiforova, M. A., et al. (2021). Neutralizing Activity of Sera From Sputnik V-Vaccinated People Against Variants of Concern (VOC: B.1.1.7, B.1.351, P.1, B.1.617.2, B.1.617.3) and Moscow Endemic SARS-CoV-2 Variants. Vaccines 9, 779. doi: $10.3390 /$ vaccines 9070779

Harvey, W. T., Carabelli, A. M., Jackson, B., G upta, R. K., Thomson, E. C., Harrison, E. M., et al. (2021). SARS-CoV-2 Variants, Spike Mutations and Immune Escape. Nat. Rev. Microbiol. 19 (7), 409-424. doi: 10.1038/s41579021-00573-0

Hoffmann, M., Kleine-Weber, H., Schroeder, S., Kruger, N., Herrler, T., Erichsen, S., et al. (2020). SARS-CoV-2 Cell Entry Depends on ACE2 and TMPRSS2 and Is Blocked by a Clinically Proven Protease Inhibitor. Cell 181, 271-280.e8. doi: 10.1016/j.cell.2020.02.052

Hoffmann, M., Arora, P., Groß, R., Seidel, A., Hörnich, B. F., Hahn, A. S., et al. (2021). SARS-CoV-2 Variants B.1.351 and P.1 Escape From Neutralizing Antibodies. Cell 184 (9), 2384-2393.e12. doi: 10.1016/j.cell.2021.03.036

Jara, A., Undurraga, E. A., González, C., Paredes, F., Fontecilla, T., Jara, G., et al. (2021). Effectiveness of an Inactivated SARS-CoV-2 Vaccine in Chile. N. Engl. J. Med. 385(10), 875-884. doi: 10.1056/NEJMoa2107715

Kandeel, M., Mohamed, M. E. M., Abd El-Lateef, H. M., Venugopala, K. N., and El-Beltagi, H. S. (2021). Omicron Variant Genome Evolution and Phylogenetics. J. Med. Virol. 1- 6. doi: 10.1002/jmv.27515

Khateeb, J., Li, Y., and Zhang, H. (2021). Emerging SARS-CoV-2 Variants of Concern and Potential Intervention Approaches. Crit. Care 25 (1), 244. doi: 10.1186/s13054-021-03662-x

Kielian, M. (2020). Enhancing Host Cell Infection by SARS-CoV-2. Science 370 (6518), 765-766. doi: 10.1126/science.abf0732

Kim, D., Lee, J. Y., Yang, J. S., Kim, J. W., Kim, V. N., and Chang, H. (2020). The Architecture of SARS-CoV-2 Transcriptome. Cell 181, 914-921.e10. doi: 10.1016/j.cell.2020.04.011

Kirola, L. (2021). Genetic Emergence of B.1.617.2 in COVID-19. New Microbes New Infect. 43, 100929. doi: 10.1016/j.nmni.2021.100929

Korber, B., Fischer, W. M., Gnanakaran, S., Yoon, H., Theiler, J., Abfalterer, W. et al. (2020). Tracking Changes in SARS-CoV-2 Spike: Evidence That D614G Increases Infectivity of the COVID-19 Virus. Cell 182, 812-827.e819. doi: 10.1016/j.cell.2020.06.043

Koyama, T., Platt, D., and Parida, L. (2020). Variant Analysis of SARS-CoV-2 Genomes. Bull. World Health Organ 98, 495-504. doi: 10.2471/BLT.20.253591

Kuzmina, A., Khalaila, Y., Voloshin, O., Keren-Naus, A., Boehm-Cohen, L., Raviv, Y., et al. (2021). SARS-CoV-2 Spike Variants Exhibit Differential Infectivity and Neutralization Resistance to Convalescent or Post-Vaccination Sera. Cell Host Microbe 29 (4), 522-528.e2. doi: 10.1016/j.chom.2021.03.008

Li, Q., Nie, J., Wu, J., Zhang, L., Ding, R., Wang, H., et al. (2021). SARS-CoV-2 501y.V2 Variants Lack Higher Infectivity But do Have Immune Escape. Cell 184 (9), 2362-2371.e9. doi: 10.1016/j.cell.2021.02.042 
Lin, J., Tang, C., Wei, H., Du, B., Chen, C., Wang, M., et al. (2021). Genomic Monitoring of SARS-CoV-2 Uncovers an Nsp1 Deletion Variant That Modulates Type I Interferon Response. Cell Host Microbe 29 (3), 489502.e8. doi: 10.1016/j.chom.2021.01.015

Liu, C., Ginn, H. M., Dejnirattisai, W., Supasa, P., Wang, B., Tuekprakhon, A., et al. (2021). Reduced Neutralization of SARS-CoV-2 B.1.617 by Vaccine and Convalescent Serum. Cell 184 (16), 4220-4236. doi: 10.1016/j.cell.2021.06.020

Liu, J., Liu, Y., Xia, H., Zou, J., Weaver, S. C., Swanson, K. A., et al. (2021). BNT162b2-Elicited Neutralization of B.1.617 and Other SARS-CoV-2 Variants. Nature 596 (7871), 273-275. doi: 10.1038/s41586-021-03693-y

Liu, Y., and Rocklöv, J. (2021). The Reproductive Number of the Delta Variant of SARS-CoV-2 Is Far Higher Compared to the Ancestral SARS-CoV-2 Virus. J. Travel. Med. 28 (7), taab124. doi: 10.1093/jtm/taab124

Liu, Z., VanBlargan, L. A., Bloyet, L. M., Rothlauf, P. W., Chen, R. E., Stumpf, S., et al. (2021). Identification of SARS-CoV-2 Spike Mutations That Attenuate Monoclonal and Serum Antibody Neutralization. Cell Host Microbe 29 (3), 477-488.e4. doi: 10.1016/j.chom.2021.01.014

Logunov, D. Y., Dolzhikova, I. V., Shcheblyakov, D. V., Tukhvatulin, A. I., Zubkova, O. V., Dzharullaeva, A. S., et al. (2021). Safety and Efficacy of an Rad26 and Rad5 Vector-Based Heterologous Prime-Boost COVID-19 Vaccine: An Interim Analysis of a Randomised Controlled Phase 3 Trial in Russia. Lancet 397 (10275), 671-681. doi: 10.1016/S0140-6736(21)00234-8

Lopez Bernal, J., Andrews, N., Gower, C., Gallagher, E., Simmons, R., Thelwall, S., et al. (2021). Effectiveness of Covid-19 Vaccines Against the B.1.617.2 (Delta) Variant. N. Engl. J. Med. 385 (7), 585-594. doi: 10.1056/NEJMoa2108891

Lustig, Y., Zuckerman, N., Nemet, I., Atari, N., Kliker, L., Regev-Yochay, G., et al. (2021). Neutralising Capacity Against Delta (B.1.617.2) and Other Variants of Concern Following Comirnaty (BNT162b2, BioNTech/Pfizer) Vaccination in Health Care Workers, Israel. Euro. Surveill. 26 (26), 2100557. doi: 10.2807/ 1560-7917.ES.2021.26.26.2100557

Madhi, S. A., Baillie, V., Cutland, C. L., Voysey, M., Koen, A. L., Fairlie, L., et al. (2021). Efficacy of the ChAdOx1 Ncov-19 Covid-19 Vaccine Against the B.1.351 Variant. N. Engl. J. Med. 384 (20), 1885-1898. doi: 10.1056/NEJMoa2102214

Melenotte, C., Silvin, A., Goubet, A. G., Lahmar, I., Dubuisson, A., Zumla, A., et al. (2020). Immune Responses During COVID-19 Infection. Oncoimmunology 9 (1), 1807836. doi: 10.1080/2162402X.2020.1807836

Mlcochova, P., Kemp, S. A., Dhar, M. S., Papa, G., Meng, B., Ferreira, I. A. T. M., et al. (2021). SARS-CoV-2 B.1.617.2 Delta Variant Replication and Immune Evasion. Nature 599 (7883), 114-119. doi: 10.1038/s41586-021-03944-y

Moore, J. P., and Offit, P. A. (2021). SARS-CoV-2 Vaccines and the Growing Threat of Viral Variants. JAMA 325 (9), 821-822. doi: 10.1001/jama.2021.1114

Muik, A., Wallisch, A. K., Sänger, B., Swanson, K. A., Mühl, J., Chen, W., et al. (2021). Neutralization of SARS-CoV-2 Lineage B.1.1.7 Pseudovirus by BNT162b2 Vaccine-Elicited Human Sera. Science 371 (6534), 1152-1153. doi: $10.1126 /$ science.abg6105

Nguyen, T. T., Pathirana, P. N., Nguyen, T., Nguyen, Q. V. H., Bhatti, A., Nguyen, D. C., et al. (2021). Genomic Mutations and Changes in Protein Secondary Structure and Solvent Accessibility of SARS-CoV-2 (COVID-19 Virus). Sci. Rep. 11 (1), 3487. doi: 10.1038/s41598-021-83105-3

Nieto-Torres, J. L., DeDiego, M. L., Verdiá-Báguena, C., Jimenez-Guardeño, J. M., Regla-Nava, J. A., Fernandez-Delgado, R., et al. (2014). Severe Acute Respiratory Syndrome Coronavirus Envelope Protein Ion Channel Activity Promotes Virus Fitness and Pathogenesis. PloS Pathog. 10 (5), e1004077. doi: 10.1371/journal.ppat.1004077

Ni, L., Ye, F., Cheng, M. L., Feng, Y., Deng, Y. Q., Zhao, H., et al. (2020). Detection of SARS-CoV-2-Specific Humoral and Cellular Immunity in COVID-19 Convalescent Individuals. Immunity 52, 971-977.e973. doi: 10.1016/j.immuni.2020.04.023

Ong, S. W. X., Chiew, C. J., Ang, L. W., Mak, T. M., Cui, L., Toh, M. P. H. S., et al. (2021). Clinical and Virological Features of SARS-CoV-2 Variants of Concern: A Retrospective Cohort Study Comparing B.1.1.7 (Alpha), B.1.315 (Beta) and B.1.617.2 (Delta). SSRN. J. doi: 10.2139/ssrn.3861566

Oude Munnink, B. B., Sikkema, R. S., Nieuwenhuijse, D. F., Molenaar, R. J., Munger, E., Molenkamp, R., et al. (2021). Transmission of SARS-CoV-2 on Mink Farms be- Tween Humans and Mink and Back to Humans. Science 371, 172-177. doi: 10.1126/science.abe5901

Ou, X., Liu, Y., Lei, X., Li, P., Mi, D., Ren, L., et al. (2020). Characterization of Spike Glycoprotein of SARS-CoV-2 on Virus Entry and Its Immune Cross-Reactivity With SARS-CoV. Nat. Commun. 11, 1620. doi: 10.1038/s41467-020-15562-9
Ozono, S., Zhang, Y., Ode, H., Sano, K., Tan, T. S., Imai, K., et al. (2021). SARS-CoV-2 D614G Spike Mutation Increases Entry Efficiency With Enhanced ACE2-Binding Affinity. Nat. Commun. 12, 848. doi: 10.1038/s41467-021-21118-2

Pereira, F. (2021). SARS-CoV-2 Variants Combining Spike Mutations and the Absence of ORF8 may be More Transmissible and Require Close Monitoring. Biochem. Biophys. Res. Commun. 550, 8-14. doi: 10.1016/j.bbrc.2021.02.080

Planas, D., Veyer, D., Baidaliuk, A., Staropoli, I., Guivel-Benhassine, F., Rajah, M. M., et al. (2021). Reduced Sensitivity of SARS-CoV-2 Variant Delta to Antibody Neutralization. Nature 596 (7871), 276-280. doi: 10.1038/s41586021-03777-9

Plante, J. A., Liu, Y., Liu, J., Xia, H., Johnson, B. A., Lokugamage, K. G., et al. (2020). Spike Mutation D614G Alters SARS-CoV-2 Fitness. Nature 592 (7852), 116-121. doi: 10.1038/s41586-020-2895-3

Plante, J. A., Mitchell, B. M., Plante, K. S., Debbink, K., Weaver, S. C., and Menachery, V. D. (2021). The Variant Gambit: COVID-19's Next Move. Cell Host Microbe 29 (4), 508-515. doi: 10.1016/j.chom.2021.02.020

Polack, F. P., Thomas, S. J., Kitchin, N., Absalon, J., Gurtman, A., Lockhart, S., et al. (2020). Safety and Efficacy of the BNT162b2 mRNA Covid-19 Vaccine. N. Engl. J. Med. 383, 2603-2615. doi: 10.1056/NEJMoa2034577

Sabino, E. C., Buss, L. F., Carvalho, M. P. S., Prete, C. A. Jr., Crispim, M. A. E., Fraiji, N. A., et al. (2021). Resurgence of COVID-19 in Manaus, Brazil, Despite High Seroprevalence. Lancet 397, 452-455. doi: 10.1016/S0140-6736(21) 00183-5

Shang, J., Wan, Y., Luo, C., Ye, G., Geng, Q., Auerbach, A., et al. (2020). Cell Entry Mechanisms of SARS-CoV-2. Proc. Natl. Acad. Sci. U. S. A. 117 (21), 1172711734. doi: 10.1073/pnas.2003138117

Sheikh, A., McMenamin, J., Taylor, B., and Robertson, C. (2021). SARS-CoV-2 Delta VOC in Scotland: Demographics, Risk of Hospital Admission, and Vaccine Effectiveness. Lancet 397 (10293), 2461-2462. doi: 10.1016/s01406736(21)01358-1

Shen, X., Tang, H., McDanal, C., Wagh, K., Fischer, W., Theiler, J., et al. (2021). SARS-CoV-2 Variant B.1.1.7 Is Susceptible to Neutralizing Antibodies Elicited by Ancestral Spike Vaccines. Cell Host Microbe 29 (4), 529-539.e3. doi: $10.1016 /$ j.chom.2021.03.002

Shinde, V., Bhikha, S., Hoosain, Z., Archary, M., Bhorat, Q., Fairlie, L., et al. (2021). Efficacy of NVX-CoV2373 Covid-19 Vaccine Against the B.1.351 Variant. N. Engl. J. Med. 384 (20), 1899-1909. doi: 10.1056/NEJMoa2103055

Smith, E. C., Sexton, N. R., and Denison, M. R. (2014). Thinking Outside the Triangle: Replication Fidelity of the Largest RNA Viruses. Annu. Rev. Virol. 1 (1), 111-132. doi: 10.1146/annurev-virology-031413-085507

Snijder, E. J., Decroly, E., and Ziebuhr, J. (2016). The Nonstructural Proteins Directing Coronavirus RNA Synthesis and Processing. Adv. Virus Res. 96, 59126. doi: 10.1016/bs.aivir.2016.08.008

Starr, T. N., et al. (2020). Deep Mutational Scanning of SARS-CoV-2 Receptor Binding Domain Reveals Constraints on Folding and ACE2 Binding. Cell 182, 1295-1310.e20. doi: 10.1016/j.cell.2020.08.012

Staub, T., Arendt, V., Lasso de la Vega, E. C., Braquet, P., Michaux, C., Kohnen, M., et al. (2021). Case Series of Four Re-Infections With a SARS-CoV-2 B.1.351 Variant, Luxembourg, February 2021. Euro. Surveill. 26 (18), 2100423. doi: 10.2807/1560-7917.ES.2021.26.18.2100423

Supasa, P., Zhou, D., Dejnirattisai, W., Liu, C., Mentzer, A. J., Ginn, H. M., et al. (2021). Reduced Neutralization of SARS-CoV-2 B.1.1.7 Variant by Convalescent and Vaccine Sera. Cell 184 (8), 2201-2211.e7. doi: 10.1016/ j.cell.2021.02.033

Tan, M., Liu, Y., Zhou, R., Deng, X., Li, F., Liang, K., et al. (2020). Immunopathological Characteristics of Coronavirus Disease 2019 Cases in Guangzhou, China. Immunology 160 (3), 261-268. doi: 10.1111/imm.13223

Tang, P., Hasan, M. R., Chemaitelly, H., Yassine, H. M., Benslimane, F. M., Al Khatib, H. A., et al. (2021). BNT162b2 and mRNA-1273 COVID-19 Vaccine Effectiveness Against the SARS-CoV-2 Delta Variant in Qatar. Nat. Med. 27 (12), 2136-2143. doi: 10.1038/s41591-021-01583-4

Takeda, M. (2022). Proteolytic Activation of SARS-CoV-2 Spike Protein. Microbiol. Immunol. 66 (1), 15-23. doi: 10.1111/1348-0421.12945

Tanriover, M. D., Doğanay, H. L., Akova, M., Güner, H. R., Azap, A., Akhan, S., et al. (2021). Efficacy and Safety of an Inactivated Whole-Virion SARS-CoV-2 Vaccine (CoronaVac): Interim Results of a Double-Blind, Randomised, Placebo-Controlled, Phase 3 Trial in Turkey. Lancet 398 (10296), 213-222. doi: 10.1016/S0140-6736(21)01429-X 
Taylor, L. (2021). Covid-19: Is Manaus the Final Nail in the Coffin for Natural Herd Immunity? BMJ 372, n394. doi: 10.1136/bmj.n394

Torjesen, I. (2021). Covid-19: Omicron May Be More Transmissible Than Other Variants and Partly Resistant to Existing Vaccines, Scientists Fear. BMJ 375, n2943. doi: 10.1136/bmj.n2943

Volz, E., Hill, V., McCrone, J. T., Price, A., Jorgensen, D., O'Toole, A., et al. (2020). Evaluating the Effects of SARS-CoV-2 Spike Mutation D614G on Transmissibility and Pathogenicity. Cell S0092-8674, 31537-31543. doi: 10.1101/2020.07.31.20166082

Volz, E., Mishra, S., Chand, M., Barrett, J. C., Johnson, R., Geidelberg, L., et al. (2021). Assessing Transmissibility of SARS-CoV-2 Lineage B.1.1.7 in England. Nature 593 (7858), 266-269. doi: 10.1038/s41586-021-03470-x

Voysey, M., Clemens, S. A. C., Madhi, S. A., Weckx, L. Y., Folegatti, P. M., Aley, P. K., et al. (2020). Safety and Efficacy of the ChAdOx1 Ncov-19 Vaccine (AZD1222) Against SARS-CoV-2: An Interim Analysis of Four Randomised Controlled Trials in Brazil, South Africa, and the UK. Lancet. 397, 99-111. doi: 10.1016/S0140-6736(20)32661-1

Wang, E. C., Wu, M., Harvey, R., Kelly, G., Warchal, S., and Sawyer, C.. (2021). Neutralising Antibody Activity Against SARS-CoV-2 VOCs B.1.617.2 and B.1.351 by BNT162b2 Vaccination. Lancet 397 (10292), 2331-2333. doi: 10.1016/S0140-6736(21)01290-3

Wang, L., and Cheng, G. (2011). Sequence Analysis of the Emerging SARS-CoV-2 Variant Omicron in South Africa. J. Med. Virol. doi: 10.1002/jmv.27516

Wang, G. L., Wang, Z. Y., Duan, L. J., Meng, Q. C., Jiang, M. D., Cao, J., et al. (2021). Susceptibility of Circulating SARS-CoV-2 Variants to Neutralization. N. Engl. J. Med. 384 (24), 2354-2356. doi: 10.1056/NEJMc2103022

Wibmer, C. K., Ayres, F., Hermanus, T., Madzivhandila, M., Kgagudi, P., Oosthuysen, B., et al. (2021). SARS-CoV-2 501y.V2 Escapes Neutralization by South African COVID-19 Donor Plasma. Nat. Med. 27 (4), 622-625. doi: 10.1038/s41591-021-01285-x

Wu, K., Werner, A. P., Koch, M., Choi, A., Narayanan, E., Stewart-Jones, G. B. E., et al. (2021). Serum Neutralizing Activity Elicited by mRNA-1273 Vaccine. N. Engl. J. Med. 384 (15), 1468-1470. doi: 10.1056/NEJMc2102179

Xia, H., Cao, Z., Xie, X., Zhang, X., Chen, J. Y. C., Wang, H., et al. (2020). Evasion of Type I Interferon by SARS-CoV-2. Cell Rep. 33, 108234. doi: 10.1016/ j.celrep.2020.108234

Yao, H., Song, Y., Chen, Y., Wu, N., Xu, J., Sun, C., et al. (2020). Molecular Architecture of the SARS-CoV-2 Virus. Cell 183 (3), 730-738.e13. doi: 10.1016/j.cell.2020.09.018

Young, B. E., Fong, S. W., Chan, Y. H., Mak, T. M., Ang, L. W., Anderson, D. E., et al. (2020). Effects of a Major Deletion in the SARS-CoV-2 Genome on the
Severity of Infection and the Inflammatory Response: An Observational Cohort Study. Lancet 396, 603-611. doi: 10.1016/S0140-6736(20)31757-8

Yurkovetskiy, L., Wang, X., Pascal, K. E., Tomkins-Tinch, C., Nyalile, T. P., Wang, Y., et al. (2020). Structural and Functional Analysis of the D614G SARS-CoV-2 Spike Protein Variant. Cell 183 (3), 739-751.e8. doi: 10.1016/j.cell.2020.09.032

Zang, R., Gomez Castro, M. F., McCune, B. T., Zeng, Q., Rothlauf, P. W., Sonnek, N. M., et al. (2020). TMPRSS2 and TMPRSS4 Promote SARS-CoV-2 Infection of Human Small Intestinal Enterocytes. Sci. Immunol. 5, eabc3582. doi: 10.1126/sciimmunol.abc3582

Zhang, L., Li, Q., Liang, Z., Li, T., Liu, S., Cui, Q., et al. (2021). The Significant Immune Escape of Pseudotyped SARS-CoV-2 Variant Omicron. Emerg. Microbes Infect. 10, 1-11. doi: 10.1080/22221751.2021.2017757

Zhou, D., Dejnirattisai, W., Supasa, P., Liu, C., Mentzer, A. J., Ginn, H. M., et al. (2021). Evidence of Escape of SARS-CoV-2 Variant B.1.351 From Natural and Vaccine-Induced Sera. Cell 184 (9), 2348-2361.e6. doi: 10.1016/ j.cell.2021.02.037

Zhu, Z., Liu, G., Meng, K., Yang, L., Liu, D., and Meng, G. (2021). Rapid Spread of Mutant Alleles in Worldwide SARS-CoV-2 Strains Revealed by Genome-Wide Single Nucleotide Polymorphism and Variation Analysis. Genome Biol. Evol. 13 (2), evab015. doi: 10.1093/gbe/evab015

Zhu, N., Zhang, D., Wang, W., Li, X., Yang, B., Song, J., et al. (2020). A Novel Coronavirus From Patients With Pneumonia in Chin. N. Engl. J. Med. 382, 727-773. doi: 10.1056/NEJMoa2001017

Conflict of Interest: The authors declare that the research was conducted in the absence of any commercial or financial relationships that could be construed as a potential conflict of interest.

Publisher's Note: All claims expressed in this article are solely those of the authors and do not necessarily represent those of their affiliated organizations, or those of the publisher, the editors and the reviewers. Any product that may be evaluated in this article, or claim that may be made by its manufacturer, is not guaranteed or endorsed by the publisher.

Copyright (c) 2022 Hirabara, Serdan, Gorjao, Masi, Pithon-Curi, Covas, Curi and Durigon. This is an open-access article distributed under the terms of the Creative Commons Attribution License (CC BY). The use, distribution or reproduction in other forums is permitted, provided the original author(s) and the copyright owner(s) are credited and that the original publication in this journal is cited, in accordance with accepted academic practice. No use, distribution or reproduction is permitted which does not comply with these terms. 